\title{
La formación de lectores \\ en el campo de la Bibliotecología
}

\section{Elsa M. Ramírez Leyva \\ (COORDINADORA)}

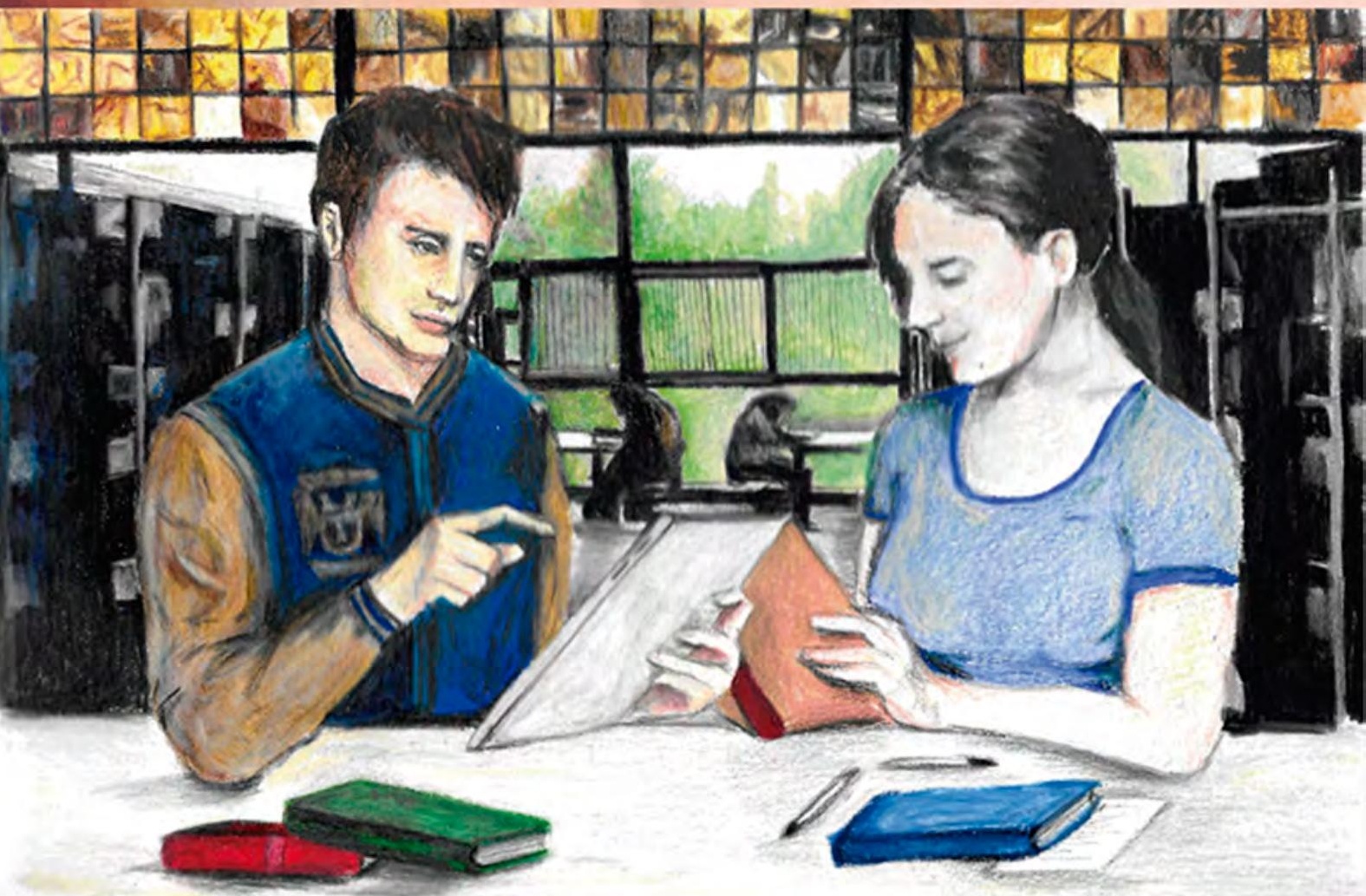




\section{La presente obra está bajo una licencia de:}

\section{http://creativecommons.org/licenses/by-nc-sa/3.0/deed.es MX}

\section{Atribución-No Comercial-Licenciamiento Reciproco 3.0 Unported}

Eres libre de:

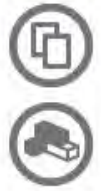

copiar, distribuir y comunicar públicamente la obra

hacer obras derivadas

Bajo las condiciones siguientes:

Atribución - Debes reconocer la autoría de la obra en los términos

especificados por el propio autor o licenciante.

No comercial - No puedes utilizar esta obra para fines comerciales.

Licenciamiento Recíproco - Si alteras, transformas o creas una obra a

partir de esta obra, solo podrás distribuir la obra resultante bajo una licencia

igual a ésta.

\section{Esto es un resumen fácilmente legible del: texto legal (de la licencia completa)}

En los casos que sea usada la presente obra, deben respetarse los términos especificados en esta licencia.
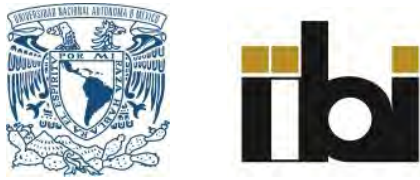
$\overline{\overline{2}}$

La formación de lectores en el campo de la Bibliotecología 


\title{
La formación de lectores en el campo de la Bibliotecología
}

\author{
Coordinadora \\ Elsa Margarita Ramírez Leyva
}

Universidad Nacional Autónoma de México 2017 

ZA3075 La formación de lectores en el campo de la Bibliotecología F67 / coordinadora Elsa Margarita Ramírez Leyva. -- México : UNAM, Instituto de Investigaciones Bibliotecológicas y de la Información, 2017.
xiii, 92 p. -- (Lectura: pasado, presente y futuro) ISBN: 978-607-02-9487-7

Alfabetización Informacional -- Estudio y Enseñanza (Superior) Orientación Bibliotecaria para Estudiantes -- Lectura I. Ramírez Leyva, Elsa M., coordinadora II. ser.

Ilustración de portada: Cecilia Ibarreche Beltrán

Diseño de portada: AGYS Alevin

Primera edición, 2017

D.R. (C) Universidad NaCional Autónoma de México

Ciudad Universitaria, 04510, Ciudad de México

Impreso y hecho en México

ISBN: 978-607-02-9487-7

Publicación dictaminada 


\section{Contenido}

PRESENTACIÓN....................................................................................................

Elsa Margarita Ramírez Leyva

APOSTILLA DE "LOS BIBLIOTECARIOS

Y LA FORMACIÓN DE LECTORES”. 1

Héctor Guillermo Alfaro López

LA FORMACIÓN DE LECTORES

¿DE QUIÉN Y DE QUÉ DEPENDE?.

Edilma Naranjo Vélez

EL BIBLIOTECARIO Y LA LECTURA:

FORMACIÓN DE BIBLIOTECARIOS COMO LECTORES.

31

Luis Ernesto Pardo Rodríguez

LOS SABERES PARA LA FORMACIÓN DE LECTORES

EN EL CAMPO DE LA BIBLIOTECOLOGÍA.

Elsa Margarita Ramírez Leyva

LA MEDIACIÓN DE LA LECTURA:

ALGUNAS CONSIDERACIONES TEÓRICAS .59

Sofía Rojas Ruíz

MEDIACIÓN, PROCESOS DEL PENSAMIENTO

Y LECTURA ANALÍTICO-CRÍTICA EN EL CURRÍCULO

DE BIBLIOTECOLOGÍA. TRILOGÍA FUNDAMENTAL

PARA LA FORMACIÓN DE LECTORES.

Johann Pirela Morillo 


\section{Presentación}

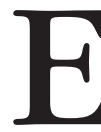

n el Seminario de Investigación de Lectura, consideramos conveniente analizar el concepto de formación, a fin de darle pertinencia en el campo bibliotecológico, ya que una de las responsabilidades de los bibliotecólogos es la formación de lectores y de usuarios, la cual adquiere relevancia en el presente siglo. En efecto, en el contexto de las sociedades del conocimiento se pondera la función de las bibliotecas como espacio de aprendizaje y actualización a lo largo de la vida. Asimismo, ellas coadyuvan en el desarrollo de habilidades de información, lo cual se está convirtiendo en una exigencia cada vez que la información, como recurso privilegiado en la sociedad de este siglo, requiere de individuos con capacidades que garanticen el uso crítico y ético para la producción y el progreso del conocimiento, para extender el bienestar social y para la preservación de la vida natural.

Al respecto del tema de la función de las bibliotecas, la UNESCO, en su informe titulado Hacia las sociedades del conocimiento, destaca que aquéllas se pueden convertir en protagonistas fundamentales del desarrollo. Recordemos que estas instituciones están comprometidas con el derecho universal a la información y el proceso de la inclusión social y cultural; asimismo con reducir las brechas 
causadas por la exclusión a la lectura y los medios de información, lo cual puede agudizarse ante los cambios de la cultura digital (2005, 70-73). Sin duda, hoy estos aspectos tornan más compleja la función formadora que podría ejercer una biblioteca, ya que se elevan las exigencias no solo en las habilidades de la lectura, sino también en las informativas, que son indispensables en el acceso y el uso de la información, las cuales tienen una diversidad de modalidades textuales, soportes y disponibilidad en el medio electrónico que está transfigurando los modos de informarse y de comunicar; así como de la educación, las actividades científicas, laborales, culturales, de entretenimiento y de la vida cotidiana en general.

Por otra parte, el conocimiento hoy en día es un elemento que puede quedar atrapado por las leyes del mercado que privilegian la innovación ante una competitividad voraz, por lo que es necesario que los ciudadanos desarrollen capacidades como un pensamiento crítico y ético, una mayor y mejor comprensión, creatividad e imaginación de altos vuelos, además de concientizar la necesidad de actualizarse de manera constante y de desarrollar mejores capacidades para leer los diferentes códigos de la realidad, entenderla e identificar oportunidades, a fin de adelantar soluciones y novedades.

Por ello, E. Morin (1999, 14) propone conocimientos que la educación del futuro debe garantizar para afrontar riesgos permanentes de error y de ilusión. Ante esto, las personas deben desarrollar facultades para mantener la lucidez y, por lo mismo, considera necesario integrar saberes de diferentes disciplinas, y también incluir a las artes y a las tecnologías cada vez que el conocimiento debe utilizarse para "reconocer la unidad y la complejidad humanas, es decir, reuniendo y organizando conocimientos dispersos en las ciencias de la naturaleza, en las ciencias humanas, la literatura y la filosofía y mostrar la unión indisoluble entre la unidad y la diversidad de todo lo que es humano".

Aunado a esto, creemos que el conocimiento es sumamente necesario para preservar el mundo natural y forjar la identidad, y así poder enfrentar las incertidumbres que inevitablemente ocasiona un mundo en constante transformación. Otro aspecto fundamental 
es la comprensión entre naciones, ya que el planeta necesita comprensiones mutuas en todos los sentidos, por lo que Morin propone una educación que integre todos los niveles educativos y todas las edades para lograr una reforma de las mentalidades. Así mismo, saber es la ética del género humano, por lo que este pensador francés considera que la ética del individuo y la especie necesita un control mutuo de la sociedad por el individuo, y del individuo por la sociedad $(2000,14)$.

Dentro de los saberes que propone Morin, hay una formación integral que tiene semejanzas con el concepto alemán de Bildung, el cual se refiere a una formación que incluye la dimensión moral, la cognitiva y la estética, que se transfieren a sus equivalentes: corazón, cabeza y mano, y a un despertar de la responsabilidad moral y de la facultad de acción. Además, se fomenta la racionalidad instrumental vinculada con la reflexión sobre el sentido humano (Noguera 2010, 17-18). Este concepto de Bildung puede orientar la formación de lectores y de usuarios en la educación, la investigación y la práctica profesional bibliotecológica, por lo que es pertinente plantear una propuesta de formación que complemente las modalidades formativas que se forjan en el hogar, pero también, y sobre todo, en la educación al interior de la institución escolar.

Por su parte, sabemos que la lectura es una actividad compleja en la que intervienen procesos neurológicos, biológicos, afectivos, sociales, culturales, e incluso económicos, cada uno de ellos tiene su procedimiento, pero al mismo tiempo se imbrican y pueden tener efectos en alguno, en la mayor parte, o en todos ellos, y causan un impacto en los lectores. Por ejemplo, una persona que se alfabetizó, pero no tiene acceso y disponibilidad a los recursos escritos para leer el proceso neurológico que interviene en esa actividad, no desarrollará ciertas facultades, esto no implica que disminuya la inteligencia de alguien, sin embargo, su patrimonio informativo, al reducirse, limita su acervo lingüístico y puede provocar exclusiones, es decir, al no comprender en su totalidad, se reduce la comunicación o limita ciertas actividades. Un caso contrario es aquella persona que tiene abundancia de recursos pero no ha tenido una mediación afectiva que propicie experiencias de 
lectura significativas, esta actividad puede reducirse a usos utilitarios y también tiene efectos en sus facultades. Y también puede existir el caso de una persona que tiene una mediación rica en experiencias afectivas e intelectuales que provocan deseo y necesidad que la motiven a esforzarse por acceder a los recursos, aunque ello le represente una dificultad.

Por otro lado, la lectura está involucrada en el desarrollo de las capacidades intelectuales $\mathrm{y}$ afectivas que cada individuo puede usar para la conformación de la identidad, usar su potencial para formarse y transformarse, realizar las funciones y actividades que se proponga, además para alcanzar una interacción social.

Por lo anterior, en el Seminario de Investigación de Lectura planteamos diferentes cuestiones que puedan dar sustento al concepto de formación, el cual implicaría reorientar la educación de los bibliotecólogos y la función formadora de estos profesionales. Por lo que se propusieron las siguientes interrogantes: ¿Qué entendemos en Bibliotecología por formación de lectores? ¿Cuáles son los márgenes que le competen a la Bibliotecología en la formación de lectores? ¿Se trata solamente de animar la práctica de la lectura por placer? ¿Qué tipo de lector pretende formar el bibliotecólogo? ¿Qué lector debe formarse para fortalecer el valor social de la biblioteca? ¿Qué es ser lector para la Bibliotecología? ¿Qué es ser un bibliotecario formador de lectores? ¿Qué se entiende por una biblioteca como un espacio de formación? ¿Qué saberes y habilidades debe desarrollar el bibliotecólogo para su propia formación y para formar lectores?

Estas cuestiones fueron las guías de la discusión y construcción de propuestas entre los integrantes del Seminario de Investigación de Lectura, y estuvieron dirigidas a desbrozar el concepto de formación e identificar los elementos para sustentar su sentido y significado en el ámbito bibliotecológico, de manera que oriente la formación del bibliotecólogo como lector, en general, y como profesional, en lo particular, a fin de desarrollar sus procesos cognitivos, saberes, aptitudes, actitudes y habilidades que requiere en su función formadora. Asimismo, se planteó la configuración de las bibliotecas como espacio de formación, información, recreación y cultura, y, con ello, favorecer experiencias intelectuales y estéticas fructíferas, de manera que cada 
persona pueda adquirir todo ello a lo largo de su vida. Del análisis y las discusiones de nuestro seminario, se derivaron resultados que dieron origen a los capítulos que integran este libro colectivo.

Elsa Margarita Ramírez Leyva

\section{BIBLIOGRAFÍA}

Morín, E. 1999. Los siete saberes necesarios para la educación del futuro. París: UNESCO.

Noguera Ramírez, C.E. 2010. "La constitución de las culturas pedagógicas modernas: una aproximación conceptual". Pedagogía y Saberes 33: 9-25.

UNESCO. 2005. Hacia las sociedades del conocimiento. París: UNESCO. 


\title{
Apostilla de "Los bibliotecarios \\ y la formación de lectores"
}

\author{
Héctor Guillermo Alfaro López \\ Universidad Nacional Autónoma de México
}

unque la formación de lectores no es una de las funciones
sustantivas de las bibliotecas - y que además se presta a
arduas polémicas respecto a su pertinencia en ellas-,este tema tiene una relevancia que permite comprender aspectos ocultos o que simplemente pasan desapercibidos en medio del quehacer cotidiano de la biblioteca y, en concreto, de los bibliotecarios. Por lo que semejante tema invita a acceder una vez más a sus múltiples aristas. De hecho, las consideraciones que se emprenderán a continuación han de considerarse como una apostilla de la reflexión que desarrollé hace algunos años en el artículo que lleva el título "Los bibliotecarios y la formación de lectores" (Alfaro López 2009). El tiempo transcurrido desde su publicación ha permitido apreciarlo desde otros ángulos y supuestos, lo que da lugar a reemprender la reflexión sobre los elementos medulares del texto para profundizar en ellos, ampliándolos y clarificándolos. José Ortega y Gasset, en un memorable aforismo, sustentaba que la dialéctica es la obligación de seguir pensando (1999). Lo que nos quiere decir el filósofo español es que el pensamiento se encuentra en permanente movimiento, tensionado por la obligación de recorrer, de comprender en sus múltiples e iridiscentes aspectos el 
objeto sobre el que centra su atención, para tornarlo mayormente legible tanto para el que lleva a cabo ese periplo intelectual, como para aquellos a los que se busca comunicar tal conocimiento.

Para iniciar el recorrido de esta apostilla, es pertinente, en primera instancia, exponer sucintamente la argumentación del artículo "Los bibliotecarios y la formación de lectores". En él partí del problema que se presenta cuando se le asigna a la biblioteca la misión para formar lectores, porque nos remite a los bibliotecarios como los agentes que han de llevar a cabo tal misión; ante ello, se pone en evidencia que no cuentan con los elementos para eso, ya que en la mayoría de los casos los bibliotecarios no suelen ser lectores. Para identificar el origen de semejante carencia, se hizo un análisis crítico de la formación bibliotecológica que reciben los bibliotecarios, lo que redundó en la explicación de que la orientación técnica sobre la que se sustenta su trayectoria educativa ha contribuido principalmente a configurarlos como no lectores, o en el mejor de los casos, como poco lectores. Para fundamentar tal observación, se recurrió a la implementación de los conceptos provenientes de las ciencias sociales como son valor de uso y valor de cambio, así como alienación.

La educación bibliotecológica se encuentra apoyada en una concepción cognoscitiva de la ciencia positivista, que desemboca en un empirismo pragmático que apela al desiderátum objetivista científico, lo que funge como barrera contra las injerencias de la subjetividad. Esta concepción, a nivel operativo, determina el procesamiento técnico de los registros gráficos, por lo que la orientación cognoscitiva respecto a estos se da en términos de exterioridad, lo que redunda en el no apropiamiento del documento. A esto hay que agregar que en este tipo de orientación educativa se puntualiza que la función primaria a la que responde tal profesión es a la de ser un intermediario, un gestor, entre el acervo bibliográfico (información) y el usuario; lo cual lleva implícita la acción de privilegiar el valor de cambio del documento y, con ello, la gestación de la alienación que tiene el bibliotecario respecto a los registros gráficos o, más exactamente, en relación a la información que contienen.

En la esfera laboral, en la que el bibliotecólogo se transfigura en bibliotecario, toda aquella formación técnica a la que fue sometido 
durante su educación se desenvuelve y consolida en la biblioteca. El registro gráfico cambia de estatus: de objeto de conocimiento a objeto de trabajo; el cual, una vez que ha pasado por el proceso técnico, está preparado para ser ofrecido al usuario, con lo que queda explícito el valor de cambio del documento. Una vez en posesión del documento, el usuario ejerce el valor de uso del mismo por mediación de la lectura. Por lo que hay que dejar establecido que el valor de uso del documento no consiste en la información contenida, ni tampoco en la simple descodificación de la misma (que es la que lleva a cabo el bibliotecario durante el procesamiento técnico del documento), sino en su lectura. La práctica de la lectura es en sí misma un fenómeno de extrema complejidad que entraña las múltiples esferas que configuran al hombre y su mundo, lo que conlleva el establecimiento de un espacio densamente simbólico.

Así, por un lado, tenemos al bibliotecario, cuya restringida actividad de organizar la información le obstruye el paso para la apropiación de la misma a través de la lectura, con lo que también en el ejercicio laboral queda alienado con respecto al documento, esto es, se establece una separación entre uno y otro al no haber una apropiación del mismo durante la lectura. Mientras que, por el otro lado, el usuario es el que tiene acceso a la dimensión informativa del documento, ejerce el valor de uso al apropiarse, a través de las múltiples variantes de la lectura, del contenido del documento. Con ello, se abre una escisión entre ambas manifestaciones del valor de los documentos, lo que desemboca en la ambivalencia del dominio entre los dos extremos, tanto del bibliotecario como del usuario, respecto a los documentos. Demos el giro de tuerca que nos conduce al aporte de esta apostilla.

En el epílogo del artículo "Los bibliotecarios...", mencionaba fugazmente el factor del contexto histórico-social que determinó la orientación técnica del campo bibliotecológico. Ahondar en este punto permite clarificar los antecedentes que van a signar la educación técnica bibliotecológica hasta nuestros días, pero también la orientación técnica del campo bibliotecológico en su conjunto, ante lo cual se presenta la vía alterna que ofrece la lectura. 
Hacia mediados del siglo XIX, se gesta el nuevo modelo de biblioteca pública en los países anglosajones, tal modelo — que puede ser considerado una revolución en la multisecular historia de las bibliotecas - es un claro producto de un contexto como el de la sociedad capitalista industrial, a la par del fenómeno del ascenso de las masas, ya que son la fuerza de trabajo que mueve a la industria, y también son los consumidores de los artículos producidos por ella. Esto se traduce en un incremento de las necesidades sociales de información, lo cual, a su vez, propicia una acción en cadena: las nuevas bibliotecas públicas requieren, para su manejo, de personal especializado, lo que favorece la apertura de escuelas para bibliotecarios que privilegian la eficiencia para organizar lo más expeditamente posible una información en constante incremento, y así ponerla a la disposición de un expansivo número de usuarios. Todo esto redundará en la constitución del campo bibliotecológico, en donde se sustenta la educación bibliotecaria en el recurso técnico más apropiado para ello.

Los antiguos bibliotecarios — verdaderos eruditos humanistasfueron consumados lectores que dirigían bibliotecas de élite, no tenían lugar en las sociedades de masas, eran cosa del pasado. Además los vientos de la época eran impulsados por la preeminencia técnica; de hecho, las tendencias que dieron forma a ese contexto propiciaron una mutación en el desenvolvimiento histórico de la técnica, la cual, al fusionarse con el conocimiento científico, dio lugar a la aparición de la tecnología que marcó con su impronta a las sociedades del siglo XX, y que será asimismo el basamento de la sociedad del conocimiento de las postrimerías de esa centuria y del presente siglo XXI. Así pues, el que la técnica se convirtiera en el corsé de la educación bibliotecaria y, más aún, del emergente campo bibliotecológico durante el siglo XIX, fue una necesidad que respondía a las fuerzas y tendencias que en ese momento estaban dando forma a la sociedad industrial.

Ahora bien, si la instauración del desiderátum técnico en el campo bibliotecológico no fue algo premeditado sino producto de las tendencias de la época, lo que resulta ahora problemático es que, una vez que el contexto que dio pauta para ello, ha pasado para 
transfigurarse en una sociedad inestable, cambiante, -en el decir del sociólogo Zygmunt Bauman, "sociedad líquida", esto es, la del capitalismo tecnológico e informático- y la técnica por sí misma no resulta suficiente para sustentar una ciencia como la Bibliotecología. Pero la técnica ha quedado profundamente arraigada como un automatismo a través del cual tienen que pasar y moldearse los conocimientos que se producen, así como la mentalidad de los integrantes de este campo. De ahí que pueda decirse que en la actualidad, el campo bibliotecológico se encuentra estatuido bajo la égida de un orden técnico y que, en cuanto tal, penetra y determina la conformación y orientación de las diversas prácticas y objetos que constituyen este campo. Lo que explica el por qué la educación bibliotecológica privilegia la formación técnica y directamente proporcional con menoscabo de la formación lectora de los estudiantes. Es preciso subrayar que aunque la técnica formó parte consustancial del desenvolvimiento de las bibliotecas a lo largo de la historia, siempre había estado supeditada a otros factores del quehacer bibliotecario. Sin embargo, en la actualidad los roles se han invertido.

Pero como se mencionó antes, paradójicamente en la era de las nuevas tecnologías de la información y su correlato, la sociedad del conocimiento, la técnica por sí misma resulta insuficiente para hacer avanzar al campo bibliotecológico. Para enfrentar el reto que ofrece el contexto fluyente, inestable y líquido de información desbordada, se requiere configurar el campo bajo un estatuto teórico que dé fundamento conceptual a las prácticas y los objetos, con lo cual se pone límite al orden técnico; lo que redunda en que a la técnica se le ponga en el lugar que verdaderamente le corresponde: como mero instrumental que ha de estar dirigido por preceptos teóricos. Sin duda, esto se reflejaría en el hecho de que la educación bibliotecológica ya no estaría solo sustentada en un fundamento técnico - lo cual despejaría nuestro campo hacia la formación lectora de los bibliotecólogos y futuros bibliotecarios-, sino que esto podría iniciar la desalienación que guardan con los documentos. Respecto a este punto, también cabe añadir unas palabras a unas ideas que plasmé en mi artículo "Los bibliotecarios...", 
donde explicaba con detalle los factores que propiciaban la alienación de los bibliotecólogos y bibliotecarios con su objeto de estudio y laboral.

El bibliotecario usa su función de intermediario entre la colección y el usuario en el valor de cambio del documento para proporcionarlo a este último, lo que implica una relación lineal, unidireccional y aséptica sin retroalimentación. También significa que, al no haber una relación bidireccional que permita la conjunción entre el valor de cambio (que detenta el bibliotecario) y el valor de uso del documento (que usufructúa el usuario), los vasos comunicantes entre uno y otro quedan cegados. Esto conlleva a que la alienación no solo se dé con respecto a los documentos, sino también en relación a los actores que se agitan en el escenario de la biblioteca. Como la raíz latina lo indica, alienus entraña en este caso la separación, el distanciamiento, entre el bibliotecario y el usuario. Así, para el primero, el usuario es una insigne fantasmagoría, que es vislumbrada a través del cristal opaco que establece el orden técnico sobre el que se erige la biblioteca y a quien hay que suministrarle información. Lo que redunda en el hecho de que el correlato del orden técnico de la biblioteca sea un ámbito permeado por la deshumanización. Dicha situación incide directamente en una de las fuentes cognoscitivas de la Bibliotecología: el humanismo.

Por su propio desenvolvimiento histórico, la biblioteca y el conocimiento bibliotecario quedaron indisolublemente afiliados al humanismo. De hecho, antes de que el humanismo apareciera perfectamente estatuido y definido en el Renacimiento, el fundamento del saber bibliotecario era de carácter humanista. Con ese punto de inflexión que son las bibliotecas públicas - y con ellas la gestación del campo bibliotecológico-, el saber bibliotecario trasmutado a ciencia bibliotecológica comenzó a pendular hacia las ciencias sociales. Y aunque algunos enfoques la enmarcan notablemente como una ciencia social, lo cierto es que nunca ha perdido su raigambre humanista, por lo que una caracterización más integral tendría que definir a la Bibliotecología como un conocimiento producto de 
la intersección entre ciencias humanas y ciencias sociales. Sin duda, esto le otorga una posición específica y diferencial respecto a las fuentes humana y social, pues es producto de ambas, pero, es preciso subrayarlo, va más allá de ellas. Para que el cruce de esa doble vertiente se haga efectiva y productiva, en primer lugar se han de recuperar los valores humanistas, para luego hacerlos extensivos a los valores sociales. De ahí que, a nivel concreto y práctico, sea pertinente iniciar con su validación en el espacio bibliotecario, y detener la alienación y su secuela, la deshumanización.

Por ello, en otro giro de tuerca, la lectura vuelve a manifestarse como una vía posible para recuperar la biblioteca no solo como espacio de concurrencia del usuario para buscar información, sino también (y principalmente) como ámbito humano y de humanización de lectores.

Como se expuso en el texto de referencia de esta apostilla, la lectura es una práctica de extrema complejidad que va más allá de la superficial descodificación de un texto. La lectura abre la puerta al vertiginoso universo simbólico que pone en juego las diversas dimensiones que integran lo humano y lo social, así como la relación con el mundo. Por esta razón, siempre quedan escorzos que solicitan renovada atención para ahondar en la comprensión de esta peculiar práctica y tornarla así un poco más legible. Al respecto, la bibliotecóloga colombiana Edilma Naranjo, retomando el trabajo que se ha hecho sobre el concepto alemán de Bildung, cuya traducción es "construcción", acentúa el proceso de construcción humana que se lleva a cabo por medio de la lectura: al potencial lector se le construye como tal y éste, a su vez, al seguir la senda de la lectura, se construye humanamente, por lo que la biblioteca puede ser el territorio idóneo para emprender la gesta de la Bildung. Sin embargo, como añadido a la propuesta de Edilma Naranjo, se puede argüir que siguiendo en el espíritu de este evocador y plástico concepto germano, que hizo refulgir sus blasones durante el periodo romántico, tenemos que considerar su correlato: los obstáculos, los avatares que surcan la senda de la Bildung. Para los 
alemanes $^{1}$, el camino hacia la construcción: el autodescubrimiento y su colofón, la autorrealización, se alcanza a través de superar los obstáculos que se encuentran a lo largo del camino; de hecho, la condición de posibilidad de la construcción son los avatares mismos por los que atraviesa el individuo en su trayectoria existencial.

Esta dimensión de la Bildung, traducida en clave lectora, puede expresarse en la lectura como un proceso de construcción en el que se tienen que superar obstáculos de múltiple índole, tanto a nivel individual como social, para que el individuo pueda construirse y realizarse como un lector. En el caso del bibliotecario, es para superar una formación técnica encauzada a privilegiar el valor de cambio del documento, y en el caso del usuario para enfrentar todos los obstáculos personales, familiares y sociales que suelen cercar su trayectoria hacia la lectura, lo que es particularmente acuciante en sociedades con bajos niveles educativos y culturales.

Así, tanto para bibliotecarios como para usuarios, el territorio para superar los obstáculos y alcanzar la construcción como lectores viene a ser el espacio bibliotecario. Mas ese último obstáculo por el que tendrían que pasar ambos, es el reconocimiento mutuo como lectores. Por esto, la Bildung no sólo culmina con la autorrealización como lector, sino también con el reconocimiento y diálogo con el otro lector, y en sí con los demás lectores: la lectura como construcción humanística y la biblioteca como su escenario.

1 Aunque la idea de Bildung hunde sus raíces históricas en la cultura y la mentalidad alemana, fue durante el periodo romántico cuando floreció en la narrativa con el género de la Bildungsroman, textualmente novela de construcción (el ejemplo representativo es la novela de W. Goethe Los años de peregrinaje del joven Wilhelm Meister). En esta obra, el protagonista pasa por una amplia variedad de peripecias a través de las cuales se construye y realiza interiormente. Llevado este género al territorio filosófico, Hegel lo representa principalmente en su obra Fenomenología del espíritu, que muestra los avatares por los que pasa el espíritu (puro, enajenado y absoluto) hasta alcanzar su realización con el establecimiento de Estado, el cual significa la fase del espíritu absoluto y, por lo tanto, de su autoconocimiento. 
Por último, ese reconocimiento como lectores permitirá el despliegue de la comprensión y con ello el ejercicio de los múltiples tipos de lectura y su imbricación mutua.

El camino que conduce a la construcción de un lector en algún momento tiene que pasar por uno de sus principales avatares: la comprensión, que es la vía real que conduce a la profundidad del contenido, al penetrar en los múltiples estratos de los textos, hace legible su sentido. Por supuesto la comprensión es la antípoda de la lectura funcional: transitar de esta última hacia aquélla implica transgredir una serie de obstáculos, entre ellos zanjar la distancia con que oficialmente se han escindido los tipos de lectura. Por un lado, la lectura intelectual y, por el otro, la lectura placentera. Con la primera se asocian determinados textos, como son los de las reconocidas áreas del conocimiento, tales como las humanidades, las ciencias sociales y las científicas; mientras que a la segunda se le correlaciona con los textos "lúdicos", esto es, literarios. A estos dos tipos de lectura se les ha explicado de diversas maneras, categorizando sus especificidades y diferencias mutuas; incluso visualmente se les ha representado codificadamente por medio de la pintura y la fotografía (Raya Alonso 2015). Así, tanto el discurso como las imágenes han conformado dos visiones-versiones claramente delimitadas y diferenciadas que han quedado estatuidas y consolidadas para su estudio y su ejercicio, e incluso se arraigan en la hondura del imaginario colectivo. La oficialización de semejante bipolaridad de la lectura ha confundido las continuidades del entramado que se dan, o pueden darse, entre el intelecto y el placer de la lectura.

Decir que en un texto de filosofía, altamente abstracto, o de ciencia, sumamente técnico, puede encontrarse placer suena a despropósito; o, por el contrario, que la lectura de una novela o poema es una experiencia rigurosa y extremadamente intelectual, linda en un contrasentido. Pero como se adelantó líneas arriba, la respuesta se encuentra en la comprensión, que es la que establece los vasos comunicantes entre una lectura y la otra. Entendida de manera amplia, la comprensión significa superar lo desconocido, lo que era una barrera y, por ende, es un acto de liberación que nos abre un horizonte de posibilidades, lo que arrastra como cauda el gozo. Superar un obstáculo a través de comprender qué es y por qué se nos 
resistía redunda en un profundo placer. De ahí que la comprensión, al desplegarse en el territorio de la lectura, conduce a rebasar las dificultades que se presentan ante un texto, sea de la índole que sea, para hacer legible sus contenidos más recónditos, adquirir así sentido y, con ello, la satisfacción intelectual y el placer lúdico o, mejor aún, el placer intelectual (y hasta corporal) de la apropiación lectora de un texto, sea filosófico, literario, científico o de cualquier otra naturaleza.

Así, tanto el bibliotecario como el usuario podrán emprender la Bildung para configurarse como lectores que han podido trasgredir las fronteras de los tipos de lectura, para alcanzar una forma más integral de la lectura. Esto, además, les abre el camino a los diversos acervos, sean especializados o no, de todo tipo de bibliotecas, las cuales en conjunto se constituyen en el ámbito cultural par excellence, que brinda a través de los libros, sean de la disciplina o género que sean, la información y el conocimiento para ser asimilados y apropiados por mediación de la lectura, una lectura que no conoce fronteras entre placer e intelecto, una lectura que se realiza en cuanto tal como placer intelectual, tanto para bibliotecarios como usuarios, y hace de la biblioteca un ámbito signado por la humanización.

La biblioteca, convertida en una caja de resonancia de la lectura y como práctica de construcción humana, podrá asumir, ahora sí, el rol que por derecho le corresponde en la formación de lectores.

\section{BiBLIOGRAFÍA}

Alfaro López, H, G. 2010. "La biblioteca como espacio alienado de la lectura". En Memoria del XXVII Coloquio de Investigación Bibliotecológica y sobre la información, compilado por Jaime Ríos Orteg y Juan J. Calva González. México: CUIB-UNAM. 
— 2010. "La lectura como proceso de comprensión y conocimiento científico". Investigación Bibliotecológica: Archivonomía, Bibliotecología e Información 24, 50 (enero-abril): 35-47.

2010. "La lectura o los caminos de la comprensión y el poder". Biblioteca Universitaria. Revista de la Dirección General de Bibliotecas de la UNAM, Nueva época 13, 1 (enero-junio): 74-80.

— 2009. "El obstáculo epistemológico y la biblioteca". En Memoria del XXVI Coloquio de Investigación Bibliotecológica y sobre la información. México: CUIB-UNAM.

— 2009. "Los bibliotecarios y la formación de lectores”. Investigación Bibliotecológica: Archivonomía, Bibliotecología e Información 23, 49 (septiembre-diciembre): 179-195.

2009. Introducción a la lectura de la imagen. México: DGB-UNAM.

- 2007. Comprender y vivir la lectura. México: DGB-UNAM.

Bahloul, J. 2002. Lecturas precarias: estudio sociológico sobre los "poco lectores". México: Fondo de Cultura Económica.

Bloom, H. 2000. Cómo leer y por qué. España: Anagrama.

Cassany, D. 2006. Tras las líneas: sobre la lectura contemporánea. Barcelona: Anagrama.

Chartier, A.M. 2004. Enseñar a leer y escribir: una aproximación histórica. México: Fondo de Cultura Económica.

Chartier, R. 2000. Las revoluciones de la cultura escrita: diálogo e intervenciones. Barcelona: Gedisa.

Ferreiro, E. 2000. Cultura escrita y educación. 2da. ed. México: Fondo de Cultura Económica. 
Jamet, E. 2006. Lectura y éxito escolar. Buenos Aires: Fondo de Cultura Económica.

Lerner, D. 2003. Leer y escribir en la escuela: lo real, lo posible y lo necesario. México: Fondo de Cultura Económica.

Littau, K. 2008. Teorías de la lectura. Libros, cuerpos y bibliomanía. Buenos Aires: Manantial.

Lahire B., comp. 2004. Sociología de la lectura. Barcelona: Gedisa.

López Yepes, J., ed. 2004. Diccionario Enciclopédico de Ciencias de la Documentación. Vol.1. España: Síntesis.

Marina, J. A. y M. de la Válgoma. (2005). La magia de leer. Barcelona: Plaza \& Janes.

Martínez de Sousa, J. 1993. Diccionario de bibliología y ciencias afines. España: Fundación Germán Sánchez Ruipérez.

Morin, E. 1994. Introducción al pensamiento complejo. España: Gedisa.

Ortega y Gasset, J. 1999. Origen y epílogo de la Filosofía. España: Fondo de Cultura Económica.

Petit, M. 2001. Lecturas: del espacio íntimo al espacio público. México: Fondo de Cultura Económica.

Ramírez Leyva, E. M., comp. 2008. Tercer Seminario Lectura: pasado, presente y futuro ¿Extinción o transfiguración del lector? México: CUIB-UNAM.

Raya Alonso, G. L. 2015. "Un acercamiento bibliotecológico a la representación visual de las lectoras en el siglo XX". Tesis de maestría, Universidad Autónoma de México. 
Rodríguez Gallardo, A., 2008. "Comentario". La biblioteca pública y la formación de lectores en la sociedad de la información. Memoria. Coordinadora E. M. Ramírez Leyva, 182. México: CUIB-UNAM.

Smith, F. 1985. Comprensión de la lectura: análisis psicolingüístico de la lectura y su aprendizaje. México: Trillas. 


\title{
La formación de lectores ¿de quién y de qué depende?
}

\author{
Edilma NARANJo VÉLEZ \\ Universidad de Antioquia, Colombia
}

\begin{abstract}
Pues eso soy yo de raíz desde el comienzo, tirando, atrayendo, levantando, elevando, alguien que tira, que cría y corrige, que no en vano se dijo a sí mismo en otro tiempo ;llega a ser el que eres! FRIEDRICH NIETZSCHE
\end{abstract}

\section{INTRODUCCIÓN}

T a biblioteca es una institución que se caracteriza por los diversos valores que alberga, uno de ellos es el social, el cual se refleja en las políticas trazadas, los objetivos planteados, y los servicios y programas que ofrece, entre otros. También en ella se desarrolla una serie de actividades que permiten su fortalecimiento, especialmente cuando se observa la necesidad de que los miembros de la comunidad en los que está inserta se vean beneficiados, concretamente con el acceso, el uso y la transformación de la información en conocimiento, lo cual intrínsecamente requiere de la lectura. 
Así, en este capítulo se presenta el producto de un trabajo de investigación de varios años, revestido, sin embargo, de dudas e incertidumbres para generar el análisis y la reflexión alrededor del derecho y, en muchas ocasiones, el deber que tienen los ciudadanos en países como los latinoamericanos, de acceder a la información y su lectura, pero también de escribir, donde el compromiso por hacer cumplir tales derechos lo asumen unos pocos. Este es el caso de la biblioteca que implementa programas de formación de lectores y de usuarios, lo cual, se supone, aumenta su valor social.

En este entorno, estamos hablando de una lectura en la que el lector debe conocer el contexto del autor, al igual que el propio, los cuales están imbuidos de situaciones históricas, sociales y políticas, y muestran así la relación que existe entre los contextos del autor y del lector.

Se aborda, entonces, el concepto de la lectura, la biblioteca y su valor social, se discute el concepto de formación y se presenta la relación entre biblioteca y la formación de lectores. Estos elementos se conjugan a medida que avanza la escritura para mostrar cuán importante es recordar que lo esencial es ser-en-el-mundo.

\section{LA LECTURA}

La lectura es un proceso de carácter histórico, cultural y político, y hoy en día económico, que ha sido utilizada como un arma de poder, control y exclusión social. La lectura es marca de ciudadanía, más que de sabiduría (Ferreiro 2000).

Se ha pretendido que esta práctica se democratice para beneficio de la sociedad, pero esto solo se logrará cuando sean los mismos ciudadanos quienes, conscientes del beneficio que les trae, se apropien de ella. Desde la industria editorial, se habla de un crecimiento económico que se establece más para los sectores asociados con la producción del libro (tradicionales o en línea, sean casas editoriales o instituciones como las cámaras del libro), para quienes lo más importante es el consumo, por encima de los mismos lectores. Este crecimiento se establece desde los índices de 
lectura anuales, y se esgrime como una forma de lograr el desarrollo económico y social; pero la sola lectura o el acceso a ésta no son suficientes para alcanzarlos, puesto que es el desarrollo de un país el que genera mayor acercamiento a la lectura y a otras actividades culturales, así como a la participación ciudadana en la toma de decisiones y en la rendición de cuentas de un gobierno, donde la lectura y la escritura son los eslabones que contribuyen al logro de ese desarrollo. No obstante, se reitera, es un error pretender establecer que la lectura y la escritura sean generadoras, por sí solas, del desarrollo de una nación.

Por su parte, la escritura se observa como un derecho, porque es la forma de apropiarse de una lengua, de una cultura, que muestra cómo el sujeto es capaz de actuar, de expresarse, de comunicarse, de participar en la medida en que es autónomo, que es consciente de sus derechos y de su capacidad para comunicarse a partir de este proceso. Así mismo, la lectura es un derecho; no se debe asumir como un lujo exclusivo de una élite, en relación con el placer y la recreación, ni es una obligación para poder permanecer en la escuela, es el derecho que "permite el ejercicio pleno de la democracia” (Castrillón 2004, 12). Pero ¿cómo lograr el acceso democrático a la lectura y la escritura, de manera que no nos limitemos a los índices de consumo per cápita?

Una de las respuestas a esta pregunta puede verse reflejada en los procesos educativos, aunque también en los espacios disponibles para facilitar el cumplimiento de ese derecho a la cultura letrada. ${ }^{1}$ Es en estos espacios donde se encuentra inscrita la biblioteca, un lugar que, para coadyuvar a la democratización de esa cultura letrada, sin duda debe transformarse. Ésta es una transformación que implica garantizar el acceso a los materiales tanto impresos como electrónicos; a la vez que a otro tipo de textualidades

1 Jesús Martín Barbero habla de la cultura letrada para referirse a los miembros de la sociedad que hacen uso de los procesos de lectura y de escritura de una manera intencionada, pero también dice que esta cultura ha sido, en gran medida, "cómplice y engranaje de inequidad social y cultural" (Martín-Barbero y Lluch 2011, 19). 
o medios que revelan los procesos de lectura y de escritura de los miembros de la sociedad (radio, televisión, cine), pues se han visto permeados por las tecnologías, especialmente las de la información y la comunicación (TIC).

Para esto se precisa de unidades de información como las bibliotecas y los centros de documentación que incluyan procesos, programas y servicios que faciliten a los miembros de la comunidad en general, y no solo a la comunidad escolarizada, el acceso a la cultura letrada. De esta manera, se puede afirmar que las bibliotecas tienen entre sus responsabilidades, además de esta cultura, el facilitar el acceso a la información, el conocimiento y las expresiones artísticas y culturales.

\section{LA BIBLIOTECA Y SU VALOR SOCIAL}

La biblioteca se distingue por el papel social que cumple al facilitar a los usuarios el acceso a la información, las TIC, las artes y la cultura. Pero cabe preguntarnos: ¿esos usuarios están en condiciones de apropiarse de la información que consultan?, ¿cómo hacen para transformar esa información en conocimiento? o, ¿son solo consumidores pasivos con limitaciones para comprender una lectura? Y, de ser así, ¿la biblioteca está preparada para formar lectores críticos, cuestionadores, intrépidos, autónomos, que utilizan no un solo documento, sino varios para resolver sus necesidades de información o únicamente los anima a leer por gusto o por placer?, esto último no es negativo per se. Sin embargo, cuando se dice que la biblioteca forma lectores, es válido agregar otra pregunta: ¿los orienta para que transformen la información en conocimiento? Al respecto, hay que considerar que este conocimiento no solamente significa, por ejemplo, la elaboración de un documento, sino también la apropiación consciente de un aspecto nuevo en la vida de ese ser humano que cambió, que le permita tomar decisiones, transformar su vida y para que disfrute y se sienta satisfecho.

La biblioteca debe asumir su papel como formadora de lectores, que encuentren en la lectura un "medio de búsqueda de sentido, de 
ubicación de sí mismos en el mundo y de reconocimiento del otro [...] en donde la lectura [...] se fomente [y se estimule] como algo imprescindible en un proyecto de vida que quiera trascender una supervivencia cotidiana" (Castrillón 2004, 47). Para ello, la biblioteca tiene una misión que cumplir, en relación con la lectura del texto impreso, electrónico, visual y auditivo, y es que ésta sea un medio para asumir una posición crítica de la información que circula en la sociedad, y no cabe duda de que, para asumir esa posición, debemos expresar que la lectura es un proceso difícil, que exige esfuerzo, disciplina y concentración.

Por lo tanto, más que formar usuarios para que sepan buscar, localizar y usar la información con la ayuda de dispositivos electrónicos y digitales - lo cual es necesario realizar siempre y cuando se trascienda el consumismo de la información-, se debe formar lectores que utilicen la información, pero estando conscientes de la trascendencia que conllevan la lectura y la escritura en la transformación social de las naciones. Entonces, y solo entonces, se debería hablar de la formación de usuarios lectores, de manera que ellos, como individuos autónomos, como ciudadanos, sean conscientes al seleccionar lo que pretenden leer. En consecuencia, es necesario comprender qué es la formación de lectores y para ello se parte del concepto de formación.

\section{LA FORMACIÓN: UN CONCEPTO EN DISCUSIÓN}

La formación es un proceso dialéctico que requiere retroalimentación, es constante (nunca termina) y es horizontal la relación entre quienes participan en el proceso. Formación (Bildung) es una palabra del mundo alemán, se relaciona con la imagen, aquello que se quiere llegar a ser, que un individuo quiere proyectar de sí. Tiene una estrecha relación con la cultura. Como lo expone Gadamer, es un:

[...] Modo específicamente humano de dar forma a las disposiciones y capacidades naturales del hombre [...] es un acto de libertad del sujeto que actúa, como una obligación consigo mismo [...] en 
la formación uno se apropia por entero de aquello en lo cual y a través de lo cual uno se forma [...] en la formación alcanzada nada desaparece, sino que todo se guarda $(2005,39)$.

Se entiende así desde las ciencias del espíritu, como denomina Gadamer las ciencias sociales y humanas, que la formación, además de ser un proceso que realiza el ascenso histórico del sujeto desde lo espiritual, desde lo humano y lo social hacia lo general, también es el elemento dentro del cual se mueve quien se ha formado de este modo.

La formación es el proceso evolutivo de la educación del hombre; ella lleva a que este tenga conciencia, comprenda en el pensamiento y en la imaginación su educación y la de otros antes de que esta se realice. La formación va cambiando en la medida en que cambian los umbrales del proceso, de tal modo que siempre se está en formación y nunca formado.

Es posible asumir la formación como una experiencia semejante entre hombres, cosas y sabiduría, conservando la distancia frente a la experiencia de los hombres; puesto que cada individuo es responsable de sí mismo en su proceso formativo. Al respecto, Gadamer (2005) dice que la formación es apropiarse totalmente de todo lo que ella permite a partir de la interacción, en la cual el sujeto - como ser pensante- es consciente de sus logros y apropiaciones, en un proceso constante de desarrollo y progreso. Esto permite asumirla como el conjunto de interacciones que vive el ser humano al entrar en contacto con el mundo; es decir, es la aprehensión que el sujeto hace del mundo que lo rodea, la cual se logra por las relaciones que él mismo establece; acto en el que participan instituciones y manifestaciones sociales como la escuela, la biblioteca, la familia, la política y el lenguaje, como instancias que median en la formación de las personas, y son partícipes del proceso de adquisición de la cultura como parte del patrimonio intangible del hombre. El lenguaje permite el diálogo, la comunicación e interacción con el otro, lo que facilita comprender y apropiarse de una cultura, un idioma y una idiosincrasia, aspecto esencial del entorno que incide en el proceso formativo integral del ser. 
Como lo expresa Naranjo:

[De esta manera,] el hombre se apropia de los elementos de sí y del mundo, para reflexionarlos e introeyectactarlos [sic], lo que lo habilita para fijar sus propias relaciones al asimilar y acumular experiencias que le posibilitan adquirir gradualmente la autonomía como sujeto social y pensante que toma decisiones avaladas por él mismo, al haber adquirido habilidades de pensamiento crítico y autónomo que le permiten estar en condiciones de abstraerse, producto de su cognición, tarea que requiere esfuerzo y [compromiso] $(2005,39)$.

En consecuencia, se puede expresar que la formación como proceso conlleva la diferenciación entre los individuos, ya que es un acto único, que lo vive cada sujeto en el que prevalecen sus intereses y proyecciones, de allí que se asevere que "la formación es la apropiación subjetiva de la cultura" (Crochík 2000, 31), con la que se busca el reconocimiento y el autoreconocimiento de la persona, lo que le permitiría emanciparse para transformarse y transformar su vida; esto, para "llegar a ser" (ibid.).

Sin embargo, no puede desconocerse que "la constitución del individuo es mediatizada socialmente [y entre] más se aparta este de la cultura en la búsqueda de sí mismo, menos se individualiza. La paradoja consiste en que cuanto más considera propias sus motivaciones, más está integrado a la sociedad que impone su autonomía" (ibid., 32).

Y Naranjo agrega:

La formación es un proceso de desarrollo cuyo resultado se obtiene desde todas las influencias que con-forman al hombre, las cuales se encuentran revestidas, en algunas ocasiones, desde los procesos de enseñanza y de aprendizaje, en los que este sujeto vive en una búsqueda continua de transformación y para ello es necesario que haga uso de la inteligencia de sí y del mundo. Por eso se dice que es un ser inacabado, en continua trans-formación, autor de sí mismo (Naranjo 2005, 39). ${ }^{2}$

2 Las negritas y división de las palabras son originales del texto citado. 
Por lo tanto, este proceso está revestido del elemento humano, al saber que no estamos terminados, que vivimos una continua necesidad de formación, de dar forma al sujeto que está en construcción: "A cada ser humano le corresponde hacerse humano y, al lograrlo, continuar el proyecto de humanidad en el que está inscrito. En tal virtud, el ser humano es un ser no terminado; es una permanente y continua tarea por hacer para sí mismo y de sí mismo" (Villegas 2008, 4).

\section{LAS BIBLIOTECAS Y LA FORMACIÓN DE LECTORES}

En tanto, el lector, ese ser en permanente cambio, requiere, por momentos, de orientación, de acompañamiento, y en el espacio de la biblioteca es el bibliotecario quien debe otorgárselos, lo cual le exige a este último ser también un lector, un ser crítico de la realidad, que organice los debates alrededor de las lecturas con miras a una participación consciente de los ciudadanos en la transformación de la sociedad, pues se está contribuyendo con la construcción de la autonomía, de la libertad de un individuo mejor informado y mejor formado.

La exigencia de esa formación del bibliotecario como lector radica en que se debe entender que la formación de lectores tiene que incluir aspectos como la relación compleja entre lectura y escritura con la oralidad y con "las gramáticas tecno-perceptivas de la radio y el cine, de la televisión, el video, y las culturas digitales" (Martín-Barbero y Lluch 2011, 17), puesto que son actos de inclusión, de cohesión social y de participación ciudadana y aumento del capital cultural en las comunidades.

Una cultura en la que es necesaria la presencia de la lectura y de la escritura en el imaginario de la gente - para que pervivan en la memoria y en las experiencias sociales, al ser parte de la dimensión que constituye el bienestar social- es un factor que influye también en la calidad de vida individual y colectiva, pues al estar informado y poder comunicar lo que se ha comprendido de la información que se leyó, se podrá hablar y ser escuchado, así como 
participar activamente en los espacios en que se desenvuelve esporádica o cotidianamente (familia, barrio, grupos sociales, lugar de trabajo, reuniones y lugares de estudio).

De allí que las bibliotecas procuren posibilitar la formación de lectores integrales (desde los modos de leer y de escribir), con la pretensión de evitar la exclusión social, cultural y laboral en esta sociedad de la información. Por lo tanto, se debe propiciar una lectura que es importante para el ejercicio escolar o académico, la cual es necesario que supere su vinculación meramente instrumental de la elaboración de la tarea, y esto se logra cuando se contextualiza con la cotidianidad y los intereses personales, y se muestra cómo al comprender la actividad que se llevó a cabo, se han superado dificultades cognitivas; lo cual nos muestra que la lectura es más que entretenimiento y placer. Es recomendable que se dé una mezcla, pues es un proceso paulatino, exigente, difícil, transformador del sujeto que debería ir ligado a la cultura de la escritura, actividades propias de una sociedad de la información en la que se requiere hacer visibles la expresión creativa y la participación de los ciudadanos.

Después de analizar a la cultura letrada de esta manera, podríamos decir como Paulo Freire, quien rememora a Walter Benjamin en una entrevista realizada por Ezequiel Silva, para explicar que esta es una experiencia en la que están presentes los "nuevos modos de percibir y de sentir, de oír y de ver, de hablar y de narrar, que desordena y desconcierta la propia sensibilidad [...] de los miembros de la sociedad. Puesto que no solo leo para formarme, también me formo leyendo" (Silva 1999, 163).

Desafortunada o afortunadamente, debemos admitir una verdad que hace varios años pronunció Héctor Alfaro:

[...] Los bibliotecarios no son lectores y es, sin embargo, a ellos a quienes se les atribuye la misión de formar a los lectores, pero esa insuficiencia proviene desde su formación educativa como bibliotecólogos, la cual se enfoca al estudio de los documentos tomando en cuenta su valor de cambio y dejando de lado la parte correspondiente a su valor de uso, que es el que adquiere significación a partir de la lectura $(2009,179)$. 
Alfaro cuestiona las escuelas de Bibliotecología, la biblioteca pública y a sus administradores cuando estos últimos tal vez pretenden que por el hecho de crear servicios y programas para facilitar el acceso a la lectura, logran que aquellas sean instituciones formadoras de lectores. Si bien es cierto que la biblioteca pública ha sido reconocida por esta labor social, las demás unidades de información también tienen un compromiso con esta formación, pues todas atienden a los usuarios que usarán este insumo para alcanzar sus objetivos. Así mismo, se espera que en la biblioteca escolar o en la universitaria estas acciones no sean necesarias, teniendo en cuenta que la lectura es un acto obligatorio en las instituciones a las cuales apoyan, pues también es cierto que los niveles de calidad en la lectura no son los mejores, como lo expone Elsa M. Ramírez (2001).

Entonces, si las bibliotecas van a asumir la formación de lectores como un compromiso de su labor social, deben comprender las necesidades de los usuarios como lectores, lo cual conlleva a contar con un bibliotecario lector que supere la labor técnica que desarrolla en la biblioteca, para que acoja la formación de esos usuarios lectores y comprenda que el lector se acerca con cariño y con expectativas a la lectura, a la vez que "con seriedad y respeto hacia el texto y hacia el autor" (Freire 1999, 23).

Esto permite reconocer que en muchas ocasiones el lector no entiende lo que lee y con cierta dificultad aborda algunos textos. Por tanto, es preciso preguntarse: ¿son los bibliotecarios buenos lectores, en calidad y cantidad?, pues se pretende que la lectura sea una opción autónoma, ya que "tenemos que proponer la lectura libertaria, que es una lectura de perseverancia, de coraje de no entender lo que se leyó, que es la lectura de correr riesgos" (Freire 1999, 27).

La pregunta anterior es difícil de contestar, y más si se analiza desde un punto de vista objetivo a los programas de estudio para la formación de bibliotecólogos, puesto que pocas facultades y escuelas de Bibliotecología y estudios de la información incluyen cursos relacionados con la lectura y el proceso lector; además, al asumir la formación de lectores, los bibliotecólogos y bibliotecarios que adquieren este compromiso, deben reflexionar, analizar 
y comprender lo que significa formar, puesto que se necesitan elementos pedagógicos y didácticos para abordar esta ardua labor de mediar entre el usuario lector y la información; una labor que no debe confundirse con el fomento o la animación a la lectura (Álvarez y Giraldo 2008).

Ante ello, se necesita formar un bibliotecólogo que esté dispuesto a contribuir con la transformación social (Silva 1999), que esté en condiciones de ser mediador entre usuario e información para que, al tiempo que facilita el acceso a estos documentos, también esté preparado para orientarlo en el proceso lector y de escritura. El bibliotecario debe continuar su labor como organizador de la información, como un lector consumado que está en condiciones de discutir un tema con el lector que lo visita, o por lo menos conversar acerca de la forma de abordarlo, de analizarlo y de comprenderlo, pero también para sugerirle otros documentos que amplíen los horizontes de ese lector sin que pierda su esencia como un ser en formación y un ser inquieto. Es una situación compleja, sí, pero que es necesario encarar si realmente se quiere trascender la función social de la biblioteca alrededor de la lectura y buscar que sea una institución que se compromete con la formación del individuo y de la comunidad, en la cual se logre educar a ese bibliotecólogo y convertirlo en profesor, lector y escritor.

Los lectores son sujetos que viven en un contexto y que se encuentran revestidos de conocimientos, sentimientos, sentidos y deseos. Es preciso disponer de un proceso de formación de lectores en la Bibliotecología, de tal manera que, como lo expone Alfaro: "el círculo virtuoso de la formación de lectores de la Bibliotecología quedaría sellado: profesores lectores que forman alumnos lectores, que dan lugar a bibliotecarios lectores y que, en cuanto tales, forman usuarios lectores, los cuales a su vez retroalimentan a los bibliotecarios como lectores" (Alfaro 2009, 194).

Esto permite ver al bibliotecólogo como un profesional responsable y capaz de intervenir en dinámicas sociales que contribuyan con la formación de ciudadanos críticos que puedan asumir los desafíos de su realidad. Así, "concebimos al lector como sujeto individual pero también como sujeto colectivo. En específico lo entendemos 
como quien puede descodificar y comprender el pensamiento contenido en un texto" (Álvarez y Naranjo 2003), puesto que

el lector es quien, desde su realidad interna, da cuenta y construye el sentido del texto al que se enfrenta en un cierto contexto de lectura. El lector actúa frente al texto partiendo de su propio mundo interno, por tanto es claro que en la lectura lo que se lee no está por entero en el texto, sino también, y diríase ante todo, que en nuestra cabeza (Álvarez 2008, 26).

\section{CONSIDERACIONES FINALES}

Es necesario tener presente que la lectura surge porque se da un proceso, no se da porque sea un don, una vocación o como producto del talento de la persona. El acto de leer es un acto exigente, que presenta dificultades al lector, que requiere dedicación y, en muchas ocasiones, acompañamiento. También se debe tener claro que no todo depende del lector, puesto que existen factores que inciden indirectamente para que una persona se acerque o no a la lectura, tales como el acceso a la educación formal, el tiempo que se tiene para la lectura, el poder adquisitivo para la compra de materiales de lectura, la presencia de una red de bibliotecas bien equipada que atienda los intereses y las necesidades del lector, y que haya sido orientada a valorar la lectura como un medio para adquirir conocimientos y para divertirse.

Para finalizar, cabe preguntarse ¿por qué cuando se realizan estudios de usuarios dentro del tema del comportamiento, no se incluyen los estudios de comportamiento del lector, que quizá sería una unidad de análisis de los estudios de uso, no de la biblioteca sino de la información? Pues como dice Capurro, excluir al comportamiento del lector, "es nada menos que el rol activo del sujeto cognoscente o, en forma más concreta, del usuario, en el proceso de recuperación de la información científica en particular, así como en todo proceso informativo y comunicativo en general. No por casualidad esta teoría se refiere a un 'receptor' ('receiver') del mensaje" (Capurro 2003, s. p.). 
En realidad lo que se busca es una recuperación de la información, concebida como el contenido que portan los documentos que serán utilizados por un sujeto cognoscente, lo que permite afirmar que los documentos son portadores potenciales de conocimiento que esperan ser abordados, a partir de la lectura, por ese sujeto en conocimiento que se encuentra inmerso en un contexto social que lo "marca" como un ser-en-el-mundo (Heidegger 1973).

\section{BIBLIOGRAFÍA}

Alfaro, H. 2009. Los bibliotecarios y la formación de lectores. Investigación Bibliotecológica: Archivonomía, Bibliotecología e Información 23, 49, 179-195.

Álvarez, D. 2008. De leer, un viaje por la promoción de la lectura: guía metodológica. Medellín: Escuela Interamericana de Bibliotecología.

Álvarez, D. e Y. Giraldo. 2008. “¿Fomento, promoción o animación a la lectura?: un acercamiento conceptual a lo que la biblioteca pública hace con la lectura". En $L a b i$ blioteca pública y la formación de lectores en la sociedad de la información. Memoria. México: CUIB-UNAM, 1-19.

Álvarez, D. y E. Naranjo. 2003. La animación a la lectura: manual de acción y reflexión. Medellín: Escuela Interamericana de Bibliotecología-Universidad de Antioquia.

Capurro, R. 2003. Epistemología y ciencia de la información. http://www.capurro.de/enancib.htm. Fecha de consulta: septiembre 7, 2015.

Castrillón, S. 2004. El derecho a leer y a escribir. México: Conaculta.

Chartier, A. M. 1994. Discursos sobre la lectura. Barcelona: Gedisa.

Crochík, J. 2000. "La pseudoformación y la conciencia iluminada”. Revista Educación y Pedagogía 12: 25-38. 
Ferreiro, E. 2000. "Leer y escribir en un mundo cambiante". En Congreso de la Unión Internacional de Editores. Buenos Aires: El Congreso.

Freire, P. 1967. La educación como práctica de la libertad. Buenos Aires: Siglo XXI.

Gadamer, H. G. (2005). Verdad y método. Salamanca: Sigueme.

Heidegger, M. 1973. Ser y tiempo. Tübingen: Niemeyer.

Martín-Barbero, J. 2002. La educación desde la comunicación. Bogotá: Editorial Norma.

- y G. Lluch. 2011. Proyecto: Lectura, escritura y desarrollo en la sociedad de la información. Bogotá: CERLALC, UNESCO. http://cerlalc.org/wp-content/uploads/20 13/02/4db6c1_Lect_Esc_Des_Final.pdf. Fecha de consulta: septiembre 9, 2015.

Naranjo, E. 2005. "Formación de usuarios de la información y procesos formativos: hacia una conceptuación". Investigación Bibliotecológica: Archivonomía, Bibliotecología e Información 19,38. http://www.scielo.org. $\mathrm{mx} /$ scielo.php?script=sci_arttext\&pid=S0187-358X2005 000100003 . Fecha de consulta: agosto 31, 2015.

N. Rendón y C. Giraldo. 2006. Lineamientos y directrices para la formación de usuarios de la información. Medellín: Escuela Interamericana de Bibliotecología-Universidad de Antioquia.

Ramírez, E. 2001. "La lectura: un problema para la sociedad de la información”. Investigación Bibliotecológica: Archivonomía, Bibliotecología e Información 15, 31, 195-211.

Silva, E. 1999. "O bibliotecário e a formacao do leitor". Entrevista a Paulo Freire. Estado de leitura. 13 de enero, 1993. Organizador Valdir Heitor Barzotto. Campinas: Mercado de Letras, Associacao de Leitura do Brasil, 159-167. 
1999. "Da leitura do mundo à leitura da palabra". Entrevista de Ezequiel Teodoro da Silva a Paulo Freire. Estado de leitura. Organizador Valdir Heitor Barzotto. Campinas: Mercado de Letras, Associacao de Leitura do Brasil,19-29.

Vasco, I. 2011. Crecer como lectores, crecer como ciudadanos. Bogotá: Biblioteca Luis Ángel Arango. http://www. banrepcultural.org/sites/default/files/85192/crecer-comolectores-crecer-como-ciudadanos.pdf. Fecha de consulta: septiembre 12, 2015.

Villegas, L. 2008. "Formación: apuntes para su comprensión en la docencia universitaria". Profesorado: Revista de Curriculum y Formación del Profesorado 12, 3. http: //www.ugr.es/ recfpro/rev123COL3.pdf. Fecha de consulta: agosto 27, 2015. 


\title{
El bibliotecario y la lectura: Formación de bibliotecarios como lectores
}

\author{
Luis ERNESTO PARDo RodRígueZ \\ Universidad de La Salle, Colombia
}

\section{INTRODUCCIÓN}

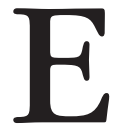

1 trabajo empírico, como campo de interés, fundamenta los procesos de enseñanza y aprendizaje en la biblioteca. Por tanto, la enseñanza es parte de la misión del bibliotecario, el contacto con usuarios y comunidades, en otras palabras, es un mediador pedagógico. El aprendizaje del bibliotecario y del usuario es recíproco mediante la lectura y el diálogo, porque son sujetos activos que indagan y cuestionan cada uno desde su realidad, cumplen indistintamente roles de emisor y receptor de información para la construcción de su propio conocimiento. Se busca siempre el impacto en los usuarios, a pesar de que, como consecuencia intrínseca, se desconozca el que se produce en el bibliotecario como mediador (Tebar Belmonte 2009, 20).

La educación durante toda la vida trasciende los presupuestos básicos entre la educación básica y la educación permanente. Cada fase en la formación del ser humano deja profundas huellas que lo consolidan como ser académico e intelectual. La educación básica fundamenta conocimientos de matemáticas, lectura, escritura y genera posibilidades para determinar la profesión que guiará su proyecto de vida (Delors y Al Mufti 1996, 20). 
En el informe La educación encierra un tesoro, Jacques Delors postuló misiones para la escuela aplicables al bibliotecario y a la biblioteca: "Es deseable que la escuela inculque el gusto y el placer por aprender, la capacidad de aprender a aprender, la curiosidad del intelecto. Imaginémonos inclusive una sociedad en que cada uno sería alternativamente educador y educando" (ibid., 21). La biblioteca tiene como misión formar usuarios y lectores; generar ambientes de enseñanza y aprendizaje desde la Alfabetización Informacional para el manejo de recursos y fuentes de información, y fortalecer las competencias de lectura y escritura para la generación de ciudadanos competentes, participativos y conscientes de la realidad socioeconómica y política de su territorio.

El bibliotecario es un educador. El reto de ser educador y educando es fascinante, se aprende del conocimiento y saberes de los usuarios; se aprende del lector curioso que indaga indistintamente realidad y ficción a través de los libros; se aprende cuando el usuario cuestiona los conocimientos del bibliotecario con preguntas que abren posibilidades inagotables de información que se materializan en documentos, datos e información concreta para la solución de necesidades de información.

El bibliotecario es un lector incansable y se forja en cada jornada de trabajo con datos actualizados de acontecimientos locales y mundiales; con novedades bibliográficas que amplían su horizonte de conocimiento y con el contacto permanente con las nuevas tecnologías que ofrecen un espacio infinito de información. Por ello, las aptitudes particulares del bibliotecario en el siglo XXI trascienden la lectura y la escritura, y, como sujeto crítico, posee habilidades comunicativas para el trabajo en equipo, capacidad resolutiva y virtudes cívicas, por lo que antepone la participación ciudadana en contextos de deberes y derechos que conlleven a la transformación individual y colectiva (Scott 2015, 10).

El bibliotecario es intelectual. Su formación intelectual es una obligación primordial, su alcance rebasa el conocimiento referencial de libros, recursos y fuentes de información. Explorar los libros y recursos bibliográficos más allá del título, lista de capítulos, introducción y prólogo hace que sus conocimientos y saberes 
tengan sentido. El bibliotecario se impregna de palabras, frases, relatos, historias, que lo hacen más sensible y competente ante su comunidad.

\section{EL BIBLIOTECARIO: LECTOR EN LA SOCIEDAD DE LA INFORMACIÓN Y DEL CONOCIMIENTO}

La esencia del bibliotecario se fundamenta en los libros, la lectura y la escritura. Tradicionalmente el bibliotecario es reconocido por su formación humanística; su capacidad para la búsqueda, recuperación y uso de información, y sus destrezas para la transformación social de comunidades. En perspectiva técnica, el bibliotecario analiza, organiza, sistematiza y dispone información para usuarios y lectores en una unidad de información. Son diversas las perspectivas que identifican una profesión de tan alta dignidad social, pero no por ello debemos dejar de advertir que el fin último del bibliotecario es hacer que usuarios, lectores y comunidades evolucionen al ritmo de las nuevas tecnologías en la sociedad de la información y el estadio superior: la sociedad del conocimiento (Secretaría de Estado de Telecomunicaciones y para la Sociedad de la Información 2003, 138).

El concepto de "Sociedad de la información" se desglosa desde la concepción de sociedad: "conjunto de seres humanos que conviven y se relacionan unos con otros. Asociación natural o pactada de seres que colaboran en trabajos o fines comunes" (Moliner 2007, 2745). Así, podemos afirmar que la sociedad de la información es un conjunto de estados, regiones, organizaciones y ciudadanos que tiene como fin último el desarrollo y el progreso de los pueblos mediante el aprovechamiento de la información (Castells 1998, 28).

La sociedad de la información privilegia la producción, distribución y manipulación de información, por ello, la proliferación de datos y el fácil acceso a fuentes de información a través de Internet son oportunidades para que el bibliotecario fortalezca, mediante la Alfabetización Informacional, los procesos de formación 
de usuarios en el manejo de las nuevas tecnologías para lograr un buen acceso a la información y con ello, la producción de nuevo conocimiento (UNESCO 2008, 15).

La sociedad del conocimiento es el estadio superior de la sociedad de la información que proyecta "cambios estructurales que posibiliten una transformación global y pluralista del desarrollo, con acento no solo en el avance tecnológico sino en la inclusión social de millones de personas que están lejos de las TIC, en especial de la Internet" (ibid., 9). El propósito de la sociedad del conocimiento es fomentar la integración de los seres humanos, propender por la equidad y el desarrollo sostenible. El conocimiento se considera instrumento definitivo para el cambio social.

Las tecnologías de la información y las comunicaciones (TIC) en la biblioteca son recursos invaluables para el acceso a información relevante para el análisis, la reflexión y la generación de propuestas para la solución de necesidades básicas de información, así como de problemáticas sociales. Las TIC extienden oportunidades con las nuevas formas de lectura que despliegan y diversifican sus ámbitos y funciones (Martín-Barbero 1992, 4). El bibliotecario, como mediador social, proyecta servicios bibliotecarios de fomento, promoción y animación a la lectura, y, como mediador informacional, genera estrategias para su formación permanente y la formación de usuarios y lectores en ambientes virtuales. La implementación y uso de dispositivos electrónicos para la consulta de material bibliográfico genera oportunidades para atraer nuevos usuarios, pero sin olvidar los libros en papel que siguen siendo un atractivo poderoso para la lectura y la escritura, a pesar de que la lectura en formatos de papel transita ya hacia la lectura en medios electrónicos. ${ }^{1}$ A finales del siglo XX e inicios del XXI, emergieron nuevas formas de aprendizaje y denominaciones diversas para la lectura:

1 La "lectura en medios electrónicos" fue una categoría emergente en la investigación como trabajo de grado en la maestría en Docencia, sobre prácticas de lectura de estudiantes y profesores del "Programa de Sistemas de Información y Documentación” de la Universidad de La Salle. El grupo de investigación lo conformaron tres archivistas y un bibliotecólogo, profesores del PSID. 
lectura electrónica, lectura digital y lectura en medios electrónicos (Pardo Rodríguez et al., 2009, 122).

Es indiscutible que hoy por hoy el mundo de lo audiovisual prima sobre el mundo del texto escrito; la fascinación por las redes sociales con enlaces a videos e imágenes, generan nuevas formas de alfabetización, nuevas condiciones del saber con nuevas formas de sensibilidad frente a la realidad (Martín-Barbero 1992, 5). Así, el reto para el bibliotecario es involucrarse, valorar y emplear en su cotidianidad las nuevas formas de lectura visual y audiovisual en su autoformación y en la formación de usuarios. El bibliotecariolector, concepto que podría sonar redundante y excluyente, representa en sí mismo la identidad del bibliotecario.

El reto es leer, pero también escribir, en esas prácticas se involucran temas relevantes para el reconocimiento de saberes locales y la reconstrucción de la memoria histórica. La oralidad juega un papel importante en la construcción de la memoria histórica de las comunidades. Todos los retos del bibliotecario están permeados por la lectura y la escritura, sin ellas el contacto con los libros, autores y corrientes de pensamiento pasan a un segundo plano y se instrumentalizan cuando el libro se valora tan solo como texto escolar y la biblioteca como un sitio para resolver tareas de la escuela.

La inclusión de la lectura y escritura en la formación de bibliotecarios es una tarea imperativa. La necesidad de construir rudimentos técnicos, académicos e intelectuales en las actividades cotidianas de la biblioteca permite acrecentar el diálogo con los usuarios y posibilitar la producción de nuevo conocimiento. En prospectiva, se puede afirmar que el aprendizaje de la realidad a través de la lectura y la escritura origina conciencia individual y colectiva en el reconocimiento de los seres humanos en la convivencia, igualdad e inclusión (Méndez Francisco, 2009, 4). La relación entre lectura y escritura genera conocimiento, la producción de conocimiento es un estadio superior de la lectura que involucra la producción académica e intelectual del bibliotecario; asimismo es un factor de crecimiento y desarrollo; la composición de manuales, guías e instructivos bibliotecarios, manifiesta su experiencia 
La formación de lectores...

bibliotecaria; la producción editorial de textos literarios de los usuarios y lectores hacen que se visibilice al bibliotecario como un gestor de conocimiento.

\section{BiBLIOGRAFÍA}

Castells, M. 1998. La era de la información: economía, sociedad y cultura. Madrid: Alianza.

Delors, J. e I. Al Mufti. 1996. La educación encierra un tesoro. Madrid: Santillana, UNESCO. Disponible en: http:// ceups.educacion.unmsm.edu.pe/proyeccion_archivos/ educacion-encierra-un-tesoro.pdf.

Martín-Barbero, J. 1992. Nuevos modos de leer. Magazín Dominical, El Espectador 474, 19-22.

Méndez Francisco, L. 2009. Conocimiento y ciencias como factores de cambio social. Instituto Superior de Formación Docente. Disponible en: http://www.isfodosu.edu. do/portal/page/portal/isfodosu/Ponencias\%20semina rio $\% 20 \mathrm{de} \% 20$ ciencias/Discurso $\% 20$ Conocimiento $\% 20 \mathrm{y} \%$ 20Ciencia\%20como\%20Factores\%20de\%20Cambio.pdf.

Moliner, M. 2007. Diccionario de uso del español. 3a. ed. Madrid: Gredos.

Pardo Rodríguez, L. E. et al. 2009. Prácticas de lectura de estudiantes del programa de Sistemas de Información, Bibliotecología y Archivística de la Universidad de la Salle. Bogotá: La Salle.

Secretaría de Estado de Telecomunicaciones y para la Sociedad de la Información. 2003. La Sociedad de la información en el siglo XXI: un requisito para el desarrollo. Madrid: Ministerio de Ciencia y Tecnología, Secretaría de Estado de Telecomunicaciones y para la Sociedad de la Información. Disponible en: https://www.itu.int/net/wsis /stocktaking/docs/activities/1103547250/sociedad-infor macion-sigloXXI-es.pdf. 
Scott, C. L. 2015. "El futuro del aprendizaje (I) ¿Por qué deben cambiar el contenido y los métodos de aprendizaje en el siglo XXI? Investigación y Prospectiva en Educación". Documentos de trabajo EFR 13, 18.

http://unesdoc.unesco.org/images/0023/002348/2348 07S.pdf.

Tebar Belmonte, L. 2009. El profesor mediador del aprendizaje. Bogotá: Magisterio.

UNESCO. 2008. Etapas hacia las Sociedades del Conocimiento. Material de referencia para comunicadores. Montevideo. Disponible en: http://unesdoc.unesco.org/ images/0017/001798/179801S.pdf. 


\title{
Los saberes para la formación de lectores en el campo de la Bibliotecología
}

\author{
Elsa Margarita RAmírez LeYVA \\ Universidad Nacional Autónoma de México
}

\section{INTRODUCCIÓN}

$\tau$ a formación de lectores y de usuarios es una de las responsabilidades del bibliotecólogo dentro de las diversas funciones que realiza en la biblioteca, entre estas la selección de los acervos, los espacios de lectura y los servicios, incluyendo los programas específicos de promoción de la lectura y el desarrollo de habilidades informativas. Todo ello está determinado por la concepción de tres aspectos intrínsecos del bibliotecólogo: los alcances de compromiso social, la lectura y la formación de lectores.

Dichos aspectos pueden diagnosticar la selección de acervos y los ambientes de lectura que habían estado enmarcados en la visión de la lectura para el estudio en solitario y en silencio; sin embargo, ahora se suman modalidades de aprendizaje colaborativas, tales como los espacios para la lectura, el acceso y uso de contenidos en un entorno digital y con recursos audiovisuales, no sin dejar de lado el hecho de que cada una de esas modalidades de lectura exige requerimientos particulares.

Otro aspecto es la mediación, acción fundamental de todo bibliotecólogo que tendría que ser el eje que articule de manera trasversal 
la educación. Al respecto, Shera señala: "Es la interfase hombre-libro la que tiene la clave hacia una filosofía de la biblioteconomía y define el contenido intelectual de la educación bibliotecológica" (1990, 40). Esta idea está inspirada en las cinco Leyes de la Bibliotecología de Ranganathan (1931), las cuales aluden al conocimiento que se debe tener tanto de los libros como de los lectores.

La mediación implica las diferentes actividades especializadas relacionadas con los medios bibliográficos documentales e informativos y, asimismo, con las características, necesidades de los lectores o usuarios, los recursos y servicios que requieren y las actividades de formación que debe ofrecer el bibliotecólogo. Con ello, la mediación logra la interacción entre ambos universos y, como proponía Shera $(1990,40)$ se logra que "el hombre y el libro se encuentren en una fructífera experiencia intelectual” y, agregaríamos, también una experiencia estética. En esa mediación se incluye la función de formadores de lectores, en donde están implicados su discurso, saberes, actitudes, aptitudes, respeto, ética y la responsabilidad e interés de promover la lectura, a fin de que los ciudadanos la asuman para el desarrollo de sus potencialidades y desplieguen sus opciones de transformación.

La formación del bibliotecólogo y de los lectores o usuarios varía en cada época. Así, en el presente siglo XXI, la cultura de la información, el conocimiento y la comunicación creadas por el hombre han participado en el desarrollo de diversos saberes, técnicas, tecnologías y artes como parte de un proceso civilizatorio. En el presente, los miembros de las sociedades del conocimiento - transformadas por la tecnología electrónica - están persuadidos a aprender nuevas modalidades de lectura, de información y de comunicación, todas ellas necesarias en el perfeccionamiento de las capacidades humanas, tales como reflexivas, dialógicas, creativas, imaginativas, afectivas, contemplativas, lúdicas; al igual que de asombro, de pensamiento crítico, de curiosidad, de comprensión o de duda. Este proceso de aprendizaje no se alcanza de una vez y para siempre, sino que se cultiva a lo largo de la vida. 


\section{LA BIBLIOTECA: ESPACIO DE FORMACIÓN DE LECTORES}

La UNESCO afirma que: "Las bibliotecas han venido desempeñando un papel fundamental en la difusión de conocimientos", y agrega que la capacidad para sacar el mejor provecho de una biblioteca ha exigido siempre un aprendizaje - a veces formal, pero en la mayoría de los casos informal- que se efectúa frecuentándola y familiarizándose progresivamente con los instrumentos bibliográficos. Y puntualiza que

la biblioteca es desde hace mucho tiempo un lugar en el que se aprende a aprender y en el que se transforma la información en conocimiento. En las sociedades basadas en el aprendizaje a lo largo de toda la vida, las bibliotecas tienen que promoverlo y facilitarlo a todos los niveles [...]. Las bibliotecas pueden además facilitar considerablemente los itinerarios de aprendizaje individualizados" (UNESCO 2005, 72-73).

Además, afirma que la biblioteca seguirá siendo un pilar de la circulación social de los conocimientos y un factor de vitalidad para las redes de aprendizaje. En efecto, sus funciones cognitivas y evolutivas hacen de ella una organización de aprendizaje por excelencia.

La biblioteca, a diferencia de otros espacios, por ejemplo el hogar, la escuela, el lugar de trabajo o las iglesias, tiene un margen de libertad para hacer de la lectura un proceso de formación, por lo que tendría que orientarse a la construcción de una conceptualización de la formación de lectores en la que se articulen los procesos racionales y emocionales, y esta sea la actividad que sustente los saberes que propone Morin. Esa función formadora de los bibliotecólogos atañe también a su propia formación, para que la biblioteca se constituya en una mediación estratégica de aprendizaje, formación, información e instrucción cultural. 


\section{LA FORMACIÓN DE LECTORES EN EL ÁMBITO BIBLIOTECOLÓGICO}

En el campo de la Bibliotecología, el concepto de "formación" se ha utilizado en los últimos años para substituir el término de "educación de usuarios", que a su vez ahora se aproxima al concepto de "alfabetización informativa" o "desarrollo de habilidades informativas". E. Naranjo encuentra que desde 1833 surgió el "interés de algunos bibliotecarios por resolver las dificultades existentes entre el usuario y la información" $(2004,40)$. La autora nos refiere que en un informe de la Universidad de Colombia se hace mención de "una instrucción sistemática que inicie a los alumnos en los métodos correctos, para que en el resto de sus vidas el trabajo en las bibliotecas pueda producirles el mayor rendimiento posible" (Naranjo 2004, 41). Además, Naranjo encuentra que en la década de 1850 las bibliotecas desarrollaron la formación de usuarios a la par del servicio de consulta o referencia. Y también refiere que Samuel Green, en 1876, escribió un artículo que permitió comprender "la importancia de los servicios de consulta para beneficiar a los usuarios, pero consideraba que ese beneficio sería real cuando se instruyera a los usuarios para bus car la información que necesitaban [...]" (ibid.). También cita a Dewey, quien afirmaba que "había llegado el tiempo de que la biblioteca fuera una escuela, el bibliotecario un maestro y el visitante se convierta en un lector que utiliza los libros como los operarios sus herramientas" (ibid.).

Por otro lado, la formación de lectores también se ha denominado de otras maneras, como fomento, promoción o animación a la lectura. Esta función se realizaba desde un siglo atrás en el ámbito de las bibliotecas universitarias de los Estados Unidos de América, durante la década de los treinta, como lo refiere Janelle M. Zauha cuando dice que la biblioteca de la Universidad de Iowa emprendió programas para promover vigorosamente la lectura por placer entre sus estudiantes, con el programa denominado University Iowa Libraries Handbook y a cuya actividad se le conocía como "The king of sports" $(1993,57)$. 
Otro autor que de igual manera alude a la función formadora de los bibliotecólogos es J. Ortega y Gasset en la "Misión del bibliotecario", ensayo que leyó en el Segundo Congreso IFLA celebrado en Madrid en 1935, y cuyas palabras ahora recordamos:

Ahora se siente la necesidad no de buscar libros —esto ha dejado de ser verdadero problema-, sino la de fomentar la lectura, la de buscar lectores. Y, en efecto, en esta etapa las bibliotecas se multiplican y con ellas el bibliotecario. Tendrá el bibliotecario del porvenir que dirigir al lector no especializado por la selva de los libros y ser el médico, el higienista de sus lecturas (Ortega y Gasset 2005, 6-7).

Inclusive en esa década se empieza a forjar la identidad de las bibliotecas públicas, como la "universidad del pueblo" (Alvin 1935), es decir, espacios para impulsar la autoeducación en los adultos.

Después J. Shera también alude a una función formadora ante las fallas de la escuela en la educación de los alumnos:

La escuela parece incapaz de ejercer influencias independientes para hacer que los niveles de aprovechamiento dependan menos de los antecedentes del niño [...]. Así, es lógico suponer que mientras más importante pueda ser la biblioteca para estimular la educación voluntaria, mayor será el rol educativo del bibliotecario $(1993,22)$.

En otras palabras, los fundamentos bibliotecológicos que proponen el axioma en el que destaca la biblioteca como mediadora, apuntan a generar experiencias fructíferas entre las comunidades y el mundo de la información documental y, agregaríamos, los recursos culturales.

Asimismo, Paulo Freire concibe a la biblioteca como un centro de cultura y no como un depósito silencioso de libros; asevera que es el factor fundamental para el perfeccionamiento y la identificación de esa forma correcta de leer el texto en relación con el contexto, y también sugiere que en ese espacio se organicen seminarios de lectura para lograr un mayor adentramiento crítico, la aprehensión de significados y una lectura estética $(2006,122)$. En estas ideas, se 
evidencia la confirmación de la biblioteca como un espacio en donde el bibliotecario tiene la responsabilidad de formar lectores críticos, no sólo de los contenidos escritos, también del mundo, y ese acto de lectura alude a la transformación de los lectores.

El conocimiento, sin embargo, no se transfiere, se crea a través de la acción sobre la realidad, es la superación del hiato dialéctico entre el sujeto y el objeto, no solo es conocer de modo diferente lo que antes se conocía, sino también conocer lo que antes no se conocía (ibid., 43). Es "un acto creado, no acto digestivo" (ibid., 83).

La formación en este campo bibliotecológico puede orientarse a crear una sinergia entre la lectura escolar y/o académica, y los diferentes géneros discursivos como el oral, el escrito, el matemático, el geométrico y el audiovisual, que creen una lectura crítica y estética, e incrementen las habilidades informativas.

Respecto a la formación de los bibliotecarios como formadores de lectores, Héctor G. Alfaro López afirma que la formación de lectores en el ámbito bibliotecario adquiere la categoría de axioma:

Un aspecto de la lectura que gradualmente cobra mayor relevancia tanto para el campo bibliotecológico como para la sociedad en general, es el papel que juega la biblioteca pública en la formación de lectores. Relevancia que incluso es puesta abiertamente de manifiesto y legitimada por la propia Federación Internacional de Asociaciones e Instituciones Bibliotecarias (IFLA), la que con la puesta en marcha del proyecto Encuesta Internacional de Lectura busca indagar y conformar un panorama sobre los servicios que las bibliotecas públicas ofrecen para la formación de lectores (2009, 181).

Alfaro agrega que la biblioteca pública, por sobre otras instituciones o instancias educativas, puede hacer tanto de los bibliotecarios como del público en general, el pistón en la formación de lectores, lo que redunda en una plusvalía para los bibliotecarios: "el que popularmente se tenga la visión de ellos como lectores, incluso, como excelentes lectores" (ibid.). Sin embargo, encuentra contradicciones en la propia formación lectora de los bibliotecólogos, e incluso pone en duda la capacidad de los bibliotecarios para formar lectores: 
"auténtica asignatura pendiente que parcializa, segmenta y limita la formación de lectores que los bibliotecarios a su vez deberían llevar a cabo con los usuarios" (ibid., 191).

Por ello, es necesario reconocer que la formación de lectores a través de actividades y programas de promoción de lectura por placer ya no es solamente una función de la biblioteca pública y escolar, ahora se extiende a las universitarias. De estas acciones, surgió el interés en 2006 de un grupo de instituciones españolas por crear la Red Internacional de Universidades Lectoras, que ahora es integrada por 46 universidades de diferentes partes del mundo, con la finalidad de impulsar proyectos y acciones para que le lectura, la escritura y la alfabetización se integre de manera transversal en la formación académica. Con ello, se observa un incremento de instituciones de educación superior que impulsan tanto la enseñanza de la lectura y la escritura académica como la promoción de la lectura por placer; al respecto de esta última también las bibliotecas han emprendido iniciativas de alto alcance. Y ya se acepta en este nivel que la lectura y la escritura no se aprenden de una vez y para siempre, sino que implican todo un proceso continuo y gradual en el que se perfeccionan, a la par que se potencian, las facultades humanas en una interacción que va en ambos sentidos.

\section{PROPUESTAS PARA LA NOCIÓN DE FORMACIÓN DE LECTORES EN EL ÁMBITO BIBLIOTECOLÓGICO}

Es bien sabido que a la lectura se le asignan diferentes funciones, tales como la pedagógica, informativa, estética, lúdica, e incluso terapéutica; y todas ellas pueden formar una unidad que hasta ahora se segmenta y vincula a un ámbito específico, como el hogareño, el escolar, el laboral, el bibliotecario y ahora el digital. Precisamente la Bildung es un concepto que integra diferentes dimensiones que corresponden con el sentido al que apunta el desarrollo integral del ser humano, es decir, hacia donde tendría también que dirigirse la formación del bibliotecólogo para emprender la función formadora que realiza. 
De acuerdo con la revisión histórica que ofrece Conrad Vilanou (2005, 219-221) sobre el concepto de la Bildung, se pueden identificar los elementos que sustentan lo que es la formación. Su origen se remonta a la paideia del Periodo Helénico, que alude a un catálogo de virtudes morales y espirituales, con el objetivo de promover la dignidad del ser humano, en donde la virtud (areté) es entendida como sinónimo de excelencia humana. Vilanou encuentra en la filosofía de Sócrates que la Paideia alude a un estado de formación constante que implica el esfuerzo por vivir y morir conforme a un planteamiento racional de la conducta humana que surge, por lo común, de una escrupulosa observación de las leyes de la polis, que son, a su vez, un reflejo de las leyes que rigen al universo. Y en Platón, la ley por la educación hizo de la legislación el instrumento para la formación de los ciudadanos en las leyes. De esta forma, se amplía el marco de la educación de una minoría de selectos a toda la comunidad, ya que para él la ley tiene una función educadora. Y durante el Periodo Helénico, la religión y la filosofía constituyeron dos cosmovisiones diferentes, la primera implica obediencia; la segunda, en cambio, que implica toda la mentalidad griega, apela al sentido de la vista, a la intuición, a la mirada y a la contemplación de las ideas además, la filosofía griega privilegia el logos, la razón, es decir, el pensamiento que se rige por la ley que rige el cosmos.

Después de la etapa de la Bildung medieval que se enmarcó después de la formación cristiana, con el paso a la modernidad, la Bildung ingreso al neo-Humanismo, el cual propone que la humanidad puede desarrollarse por medio de la formación. Desde esta perspectiva, se entiende a la formación como un proceso de humanización que tiende a elevar al hombre al máximo grado de humanidad, como valor ético y estético, y encierra un conjunto de fuerzas y facultades que, además de no escindir al hombre de la naturaleza, lo elevan por encima de ella, porque la humanidad avanza como un todo (Vilanou 2005, 219-221). Ahora , la humanidad puede contribuir a la búsqueda de un horizonte que oriente y dé sentido a la praxis educativa teniendo en cuenta aquellos aspectos de la tradición cultural occidental que han sido olvidados. Al respecto, H. G. Kotthoff y M. A. Pereyra consideran que 
con debates diversos sobre si es posible mantener los significados de la Bildung en el siglo XXI, esta tradición hoy se repiensa incluso para orientar los cambios educativos que introducen las nuevas tecnologías de las comunicaciones y la cultura virtual, significativos para un tiempo en el que la identidad, la subjetividad, la filosofía del sujeto y lo que debería significar un nuevo humanismo, deberían problematizarse con más atención y cuidado" $(2009,21)$.

Este enfoque considera la necesidad de acudir a distintos recursos culturales y a la interacción social, porque si bien es cierto que la reflexión es individual, el aprendizaje lo es más en la interacción con otros sujetos (Vilanou 2005, 219-221). Precisamente, una de las críticas que recogen Kotthoff y Pereyra de Georg Bollenbeck, para quien la teoría de la Bildung tiene postulados que ya son obsoletos y contraproducentes, como "su recurrente individualismo y las inadecuadas concepciones 'de la constitución política de la autoformadora individualidad' de la identidad de la persona" (Kotthoff y Pereyra 2009, 22). Sin embargo, proponen que la Bildung debería incluir y cubrir la formación general de los ciudadanos del siglo XXI ante "una formación que necesariamente debe ser evaluada, y no sólo y simplemente una vez y para siempre" (ibid.).

En cuanto concepto, la Bildung en Bibliotecología es analizado por E. Naranjo, en autores como Herder, Hegel, Honore, Rousseau y Gadamer, e identificó elementos que lo distinguen como un ente abstracto que se usa en campos tan diversos como el de la formación estética, la formación moral, la formación literaria, la formación social, entre otras; de allí que se dé la posibilidad de abstraerlo al campo de la Bibliotecología con los usuarios de la información (Naranjo 2004, 37). Y nosotros agregaríamos a los lectores, toda vez que la lectura es en sí un acto formativo implicado en esos campos, que abarcan parte de las dimensiones que constituyen a cada sujeto.

La lectura y la información se encuentran inmersas en dos aspectos que para Halliday son centrales: hombre social y lenguaje; al lenguaje lo considera una potencia formadora de individuos que se produce en el ámbito social. Sostiene que "uno no existe 
sin el otro, no puede haber lengua sin hombre social" (Halliday 1982, 22). Agrega que

reconocerlo no es un mero ejercicio académico, toda la teoría y toda la práctica de la educación dependen de ello, y no es exageración sugerir que gran parte de nuestros fracasos en los últimos años - el fracaso de las escuelas al hacer frente a la contaminación social- puede tener origen en la falta de un conocimiento profundo de la naturaleza de las relaciones entre la lengua y la sociedad: específicamente, de los procesos, que en grado muy apreciable son procesos lingüísticos, mediante los cuales un organismo humano se transforma en un ser social" (ibid.).

Y es oportuno considerar también en la Bildung cómo todo acto formativo es mediado por los lenguajes oral y escrito, que se comparten con el visual y sonoro, tanto del mundo natural como del artificial.

Como ya lo hemos dicho, el concepto de formación en la Bildung abarca campos diversos, tales como la formación estética, la ética, la moral, la literaria, la social, y de igual manera sumaríamos la formación académica. Dado que esta formación también se atañe al campo de la educación bibliotecológica, en la práctica profesional del bibliotecólogo la formación puede articularse en función de que es mediadora con una vertiente hacia la formación de lectores. Y esta posibilidad de articular la lectura académica, informativa, estética, ética, social y ahora digital, sería una mediación que no tiene la intención de fragmentarlas, sino de unirlas desde cualquiera de esas modalidades y puede construir más y mejores vínculos.

La perspectiva que ofrece J. Larrosa, quien también concibe a la biblioteca como un espacio privilegiado de formación, considera el concepto de la Bildung sobre las ideas de la lectura y la formación, cuyo vínculo podría pensarse como una experiencia, aunque entendiendo "experiencia" de un modo particular, es decir, la experiencia sería "lo que nos pasa. No lo que pasa, sino lo que nos pasa". Larrosa explica que "nosotros vivimos en un mundo en el que pasan muchas cosas. Todo lo que sucede en el mundo nos es inmediatamente accesible. Los libros y las obras de arte están a nuestra disposición como nunca antes lo habían estado. Nuestra 
propia vida está llena de acontecimientos. Pero, al mismo tiempo, casi nada nos pasa" (Larrosa 2003, 28).

Y en cuanto a la formación como lectura, la explica:

Implica pensarla como un tipo particular de relación. Concretamente, como una relación de producción de sentido. Desde mi punto de vista, todo lo que nos pasa puede ser considerado un texto, algo que comúnmente nuestra capacidad puede escuchar, algo a lo que tenemos que prestar atención. Es como si los libros, pero también las personas, los objetos, las obras de arte, la naturaleza, o los acontecimientos que suceden a nuestro alrededor quisieran decirnos algo. Y la formación implica necesariamente nuestra capacidad de escuchar (o de leer) eso que tienen que decimos. Una persona que no es capaz de ponerse a la escucha ha cancelado su potencial de formación y de transformación (2003, 29-30).

Al respecto, es oportuno apoyar lo anterior con la concepción de P. Freire sobre la alfabetización y la postalfabetización; no es solo descifrando, como se suele asociar a este proceso con una etapa de la formación lectora, puesto que para él implica una comprensión correcta de lo que es la palabra escrita, comprensión de la relación entre "lectura del mundo y de la palabra". Sobre las ideas de Freire, los autores H. Varela Barraza y M. Escobar Guerrero destacan que

el auténtico acto de leer es un proceso dialéctico que sintetiza la relación existente entre conocimiento-transformación del mundo y conocimiento-transformación de nosotros mismos; leer es pronunciar el mundo, es el acto que permite al hombre y a la mujer tomar distancia de su práctica (codificarla) para conocerla críticamente, volviendo a ella para transformarla y transformarse a sí mismos $(2006,17)$.

Además de los conocimientos que se adquieren en el proceso de formación, la experiencia es también necesaria para desarrollar las capacidades intelectuales y estéticas, en donde la identidad se orienta no solo a individuos capacitados para hacer, sino también para ser, por lo que aquí cobra sentido la máxima de Nietzsche: 
"llegar a ser lo es", que refiere J. Larrosa (2003, 26). Así, dichas experiencias tienen alcances en todas las actividades que realizan las personas y que retornan en una especie de formación en un ciclo permanente a lo largo de la vida. La lectura, en un amplio sentido, se involucra en ese proceso, en tanto que requiere descifrar, comprender y analizar de manera crítica los códigos del mundo natural y artificial indispensables en la construcción del saber y de experiencias de cada persona en contextos determinados para su formación y transformación.

Por tanto, estamos hablando de una formación cultural, integral y global, que vincula las ciencias con las humanidades, basada en la lectura y en el diálogo; se trata de una pedagogía que asume la responsabilidad de transmitir y acrecentar la cultura en las nuevas generaciones. Esta formación del sujeto apunta a desarrollar la racionalidad como parte de un proceso de apropiación y discusión crítica de la cultura que no se reduce solo a un plan de estudios, sino a una formación no conclusiva, que abarca la totalidad de la vida. Implica una relación dialéctica entre la individualidad y la colectividad. Y el lenguaje es considerado una potencia indispensable para acceder al saber y construirlo, descubrir nuevos horizontes para ampliar el sentido de nuestra situación y actuación límite del pensamiento, de manera que la posibilidad de apertura humana dependa de esa potencia, que es necesario desarrollar a lo largo de la vida, en la medida en que se avanza en la formación.

Lo anterior nos insta a identificar los saberes, además de lo que propone Morin, que son pertinentes a todas las disciplinas, los adecuados para que la educación bibliotecológica faculte a sus profesionales en su propia formación y como formadores de lectores:

1. Saber sobre neurociencias: conocer el proceso del desarrollo lingüístico en el sistema neuronal, ya que, en aras de alcanzar metas pedagógicas, pueden no ser adecuadas a las etapas biológicas — cerebrales y motrices - ni para todos los sujetos. 
2. Saber sobre los procesos de lectura: conocer los procesos intelectuales y estéticos involucrados en las distintas etapas que implican descifrar, comprender, desentrañar el sentido y significado de los contenidos, no solo en signos escritos, sino también en signos icónicos, sonoros y sensoriales, en los que están codificados el universo natural y el artificial.

3. Saber sobre las diferentes modalidades de lectura, tales como la literal, la crítica, la académica, la estética y/o la lúdica, todas ellas de acuerdo a los diferentes géneros propios de cada disciplina y géneros discursivos.

4. Saber sobre psicolingüística: conocer sobre la adquisición de los lenguajes y los problemas cognoscitivos, que no son únicamente de orden intelectual, también son emocionales.

5. Saber sobre el aspecto sociocultural: conocer los factores sociales y los contextos que influyen en la adquisición de los lenguajes, el acceso a los recursos de lectura, los discursos, valores, normas y creencias que configuran las representaciones y prácticas sociales de lectura y escritura.

6. Saber sobre los recursos: conocer la oferta bibliográfica y documental en diferentes formatos y soportes para realizar mediaciones asertivas entre esta oferta y los diferentes públicos lectores.

7. Saber sobre artes: conocer de manera general los lenguajes de narrativas de diferentes expresiones artísticas, a fin de vincularlas con la lectura. Asimismo, esto es necesario porque los campos laborales no son sólo la sistematización de recursos escritos.

8. Saber sobre ambientes de lectura: conocer sobre la arquitectura y la ergonomía, a fin de conformar diferentes espacios de lectura.

9. Saber sobre los procesos de educación, laborales y de entretenimiento: conocer las condiciones que los cambios generan en las modalidades de lectura, información, comunicación, las prácticas y necesidades de los lectores, para adecuar las bibliotecas, los recursos y los servicios que faciliten su acceso y uso. 
10. Saber sobre capacidades diferentes y situaciones de exclusión. Conocer los requerimientos de personas con discapacidades y limitaciones, a fin de adecuar recursos y espacios que les permitan acceder a la lectura y a la información.

11. Saber sobre modalidades de intervención: conocer métodos de promoción y animación de la lectura para diferentes tipos de lectores.

Los saberes que proponemos tendrán que complementarse -y sería lo deseable - con las experiencias de lectura propias que estos saberes produzcan en la formación de los bibliotecólogos, tanto en la dimensión intelectual como en la estética y lúdica. En palabras de Larrosa esto quiere decir que la lectura debe constituirse en formación, y la formación en lectura, para alcanzar el desarrollo de las capacidades antes ya mencionadas: reflexivas, dialógicas, creativas, imaginativas, afectivas, contemplativas, lúdicas, de asombro, de pensamiento crítico, de curiosidad, de comprensión o de duda, y con ello lograr la evolución integral del ser humano como propone la Bildung.

\section{CONCLUSIÓN}

En el contexto actual, la formación de lectores se torna más compleja, y para nuestra disciplina representa una oportunidad de fortalecer la biblioteca y la función de los bibliotecólogos en una posición estratégica, ya que dicha formación está fragmentada en dos partes, por un lado existe una lectura eferente, por el otro, una lectura estética, y esta división se da tanto en su enseñanza como en su práctica, en lugar de existir un continuum entre ambas, como propone L. Rosenblatt (1996). La primera es el tipo de lectura en la cual la atención se centra predominantemente en lo que se extrae y retiene luego del acto de la lectura, y en la segunda, el lector se dispone con presteza a centrar la atención en las vivencias que afloran durante el acto de lectura. 
Asimismo, en cuanto a los fines, usos y códigos, es necesario transformar los paradigmas heredados y construir los propios, a fin de fortalecer la visión multidimensional en la educación bibliotecológica, es decir, en la formación de los bibliotecólogos. En este aspecto, Alfaro considera fundamental modificar las relaciones con la actividad lectora, en la cual además de que es necesario darle un amplio horizonte cultural que enmarque la asignatura específica en cuestión, también lo es el poder abrir una senda que conduzca al universo de la lectura a los alumnos.

$\mathrm{Y}$ es importante recordar que ni la lectura ni la información, por muchas que sean, substituyen el trabajo de las capacidades humanas, por lo que es necesaria una formación que vaya más allá de la letra, más allá del ámbito escolar, más allá del pensamiento racional; una formación que enseñe a cada uno cómo hacerse cargo de ella para forjar el ser, el saber y el hacer.

Ahora la formación lectora debe abarcar más allá de la palabra escrita, pues es necesario aprender a leer y a crear contenidos en diferentes códigos, para comprender los contenidos y darles significado, pues como señala López Yepes: "En este nuevo contexto, el ejercicio de la lectura cobra nuevos significados dada la multiformidad de los documentos, especialmente, los documentos digitales que han dado lugar, entre otras manifestaciones, a la llamada lectura electrónica o social, caracterizada por la posibilidad de compartir y modificar contenidos" (2015, 183). Estas modalidades de lectura hacen necesario el desarrollo de nuevas capacidades y de todos los sentidos para la interacción con los diferentes códigos.

Pero es necesario que esta lectura, ahora en el ámbito digital, se libere también de la orientación puramente pragmática y apunte a ese acto de leer al que aluden los autores antes mencionados. Así, entonces, es sumamente indispensable que la formación en los cambios sociales, culturales y tecnológicos de este siglo, que privilegian la racionalidad, la velocidad, la banalidad, la facilidad, la comodidad, el consumismo y el espectáculo en el ámbito bibliotecológico, se oriente hacia el desarrollo de todas las capacidades, para que la creatividad, la imaginación, las experiencias y los saberes no sean devorados por el mercado y la inmensa oferta 
de contenidos. Por tanto, es necesario que los lectores aprendan a gobernar la lectura, para construir relaciones y asociaciones intelectuales y estéticas, y darle sentido y significado a los contenidos que elige, pero también debe aprender a cultivar la lectura del mundo, para que ella le permita actuar de manera ética y humana.

La cultura del presente siglo está transfigurando las representaciones y las prácticas sociales en dos ámbitos de la vida humana que, desde su origen, han sido fundamentales para la sobrevivencia y civilización de nuestra especie, me refiero a la información y la comunicación. Por la necesidad de ellas, y gracias a ellas, se han desarrollado el lenguaje con sus diferentes particularidades, así como las capacidades humanas para usar los conocimientos, las artes y los artefactos de manera lúcida.

Los avances científicos y tecnológicos han abierto nuevas formas de poder; sin embargo, no todo se ha resuelto, todavía convivimos en tensión con los extremos, por un lado, las creaciones más elevadas y bellas; y por el otro, la barbarie, la pobreza, las exclusiones, la ignorancia, el racismo, la satisfacción insaciable, la preferencia de lo material y el poder sobre el cuidado y respeto a lo humano y al ecosistema. Por lo mismo, es fundamental en la formación de los ciudadanos y, en particular, en la universitaria, como afirma J. A. González, el desarrollo consciente, crítico y colectivo, y el cultivo de tres culturas: de la información, del conocimiento y de la comunicación, que se enfocan en otras tantas actividades complejas y elementales humanas. Consideramos que la lectura es una actividad que tiene una función esencial en el desarrollo de las capacidades involucradas en el cultivo de esas culturas.

Sobre el modelo de la cultura informativa del proyecto de las sociedades del conocimiento, la UNESCO observa rasgos prometedores y al mismo tiempo inquietantes, a causa de la brecha cognitiva que todavía persiste entre los países y al interior de las mismas sociedades, y, ahora, corre el riesgo de ahondarse e incluso puede provocar otras grietas muy profundas dentro de cada sociedad.

Sin embargo, creemos que la Bibliotecología puede cimentar un camino que conduzca a integrar el concepto de Bildung, que da sustento a los saberes propuestos por Morin, en el campo de la 
Bibliotecología, a fin de que la lectura sea en sí misma un acto formativo ético, responsable, pleno y lúcido en el que cada persona desarrolle y transforme a lo largo de su vida sus potencialidades para alcanzar el bien vivir, y pueda construir la armonía con sus congéneres y con la naturaleza.

\section{BIBLIOGRAFÍA}

Alfaro López, H. G. 2009. Los bibliotecarios y la formación de lectores. Investigación Bibliotecológica 23, 49,: 175195. http://www.scielo.org.mx/scielo.php?script=sci_art text\&pid=S0187-358X2009000300007\&lng=es\&tlng=es.

Alvin, J. 1935. The Public Library: A People's University. Nueva York: ALA.

Bollenbeck, G. 1994. Bildung und Kultur: Glanz und Elend eines deutschen Deutungsmuster. Fráncfort, del Meno/Leipzig: Insel Verlag.

Freire, P. 2006. "Alfabetización de adultos y bibliotecas populares: una introducción". La importancia de leer y el proceso de liberación, 121-122. 18a. ed. México: Siglo XXI.

González S., J. A. 2007. "Por una cultura de la información”. En Cibercultur@e iniciación en la investigación, coordinado por J.A. González, J. A. Amozurrutia y M. Mass, 22. México: Conaculta/Instituto Mexiquense de Cultura/UNAM/CEICH.

Halliday, M. A. K. 1982. El lenguaje como semiótica social. Interpretación social del lenguaje y del significado. México: Fondo de Cultura Económica. 


\section{La formación de lectores...}

Kotthoff Hans, G. y M. A. Pereyra. 2009. La experiencia del PISA en Alemania: recepción, reformas recientes y reflexiones sobre un sistema educativo en cambio. Profeso rado, Revista de Currículum y Formación del Profesorado 13, 2, 1-25. Disponible en: https://www.ugr.es/ recf pro/rev132ed.pdf.

Larrosa, J. 2003. La experiencia de la lectura. Estudios sobre literatura y formación. México: Fondo de Cultura Económica.

López Yepes, J. 2015. "La función de la literatura y el cine en la lectura crítica. La despedida de Héctor y Andrómaca en La Ilíada". En Tendencias de la lectura en la universidad. Colección Lectura: Pasado, Presente y Futuro, coordinado por Elsa M. Ramírez Leyva, 182-203. IIBI-UNAM. Disponible en: 132.248.242.6/ publica/con mutarl.php?arch=1\&idx=292.

Morin, E. 1999. Los siete saberes necesarios para la educación del futuro. París: UNESCO.

Naranjo, E. 2004. Formación de usuarios de la información y procesos formativos: hacia una conceptuación. Investigación Bibliotecológica 19, 38, 33-60. Disponible en: http://www.scielo.org.mx/scielo.php?script=sci_arttex t\&pid=S0187-358X2005000100003\&lng=es\&tlng=es.

Ortega y Gasset, J. 2005. Misión del bibliotecario. México: Conaculta, DGB.

Ranganathan, S. R. 1931. The Five Laws of Library Science. Londres: Edward Goldston. (Madras Library Association. Publicaction Series, 2). Disponible en: http://arizo na.openrepository.com/arizona/bitstream/10150/105454 /3/PrefM.pdf

Rosenblatt, L. M. 1996. "La teoría transaccional de la lectura y la escritura". Didáctica de la lengua 1. Disponible en: [http://didacticadelalenguauno.blogspot.co.uk/2010/ 09/el---modelo---transaccional---la---teoria.html. 
Shera, J. 1990. Fundamentos de la educación bibliotecológica. México: CUIB -UNAM.

UNESCO. 2005. Hacia las Sociedades del Conocimiento. París: UNESCO. http://unesdoc.unesco.org/images/0014 /001419/141908s.pdf.

Varela Barraza, H. y Escobar Guerrero, M. 2006. "Introducción". En La importancia de leer y el proceso de liberación, 7-19. 18a. ed. México: Siglo XXI.

Vilanou Torrano, C. 2001. De la 'Bildung' a la pedagogía hermenéutica. Ars Brevis 7: 255-279.

Vilanou Torrano, C. 2005. La formación entre la tradición y la diferencia: humanismo, hermenéutica y diálogo. Revista de ciencias de la educación 202: 255-278.

Zauha, J. M. 1993. Recreational Reading in Academic Browsing Rooms: Resources for Readers' Advisory. Collection Building 12, 3/4:, 57-62. 


\title{
La mediación de la lectura: Algunas consideraciones teóricas
}

\author{
SOFÍA Rojas Ruíz \\ Universidad Nacional Autónoma de México
}

\section{INTRODUCCIÓN}

L

a mediación como concepto se ha empleado en diversas disciplinas con la base del Derecho (mediación familiar, civil, penal, (mediación cultural, mediación intercultural, animación sociocultural); lo pedagógico (mediación pedagógica, mediación psicopedagógica, mediación educativa, mediación tecnológica, mediación escolar), y lo referente a las prácticas lectoras (mediación de lectura).

Hemos separado la mediación de lectura, ya que, al no incluirse dentro de las prácticas pedagógicas y culturales antes mencionadas, no obstante las afinidades con las que cuenta, ciertamente posee características propias que serán desarrolladas a lo largo del capítulo.

La mediación de lectura a su vez puede contener varias prácticas independientes: la animación, invitación, promoción, intervención lectora, biblioterapia, entre otras.

Así, la estructura conceptual que proponemos - que servirá de base para la conformación de este texto- es la siguiente: 
La formación de lectores...

\begin{tabular}{|l|l|l|l|}
\hline \multicolumn{1}{|c|}{ Derecho } & \multicolumn{1}{c|}{ Cultura } & \multicolumn{1}{c|}{ Pedagogía } & \multicolumn{1}{c|}{ Lectura } \\
\hline Familiar & Cultural & Tradicional & Animación \\
\hline Civil & Intercultural & Tecnológica & Invitación \\
\hline Penal & De bienes culturales & Educativa & Promoción \\
\hline Mercantil & $\begin{array}{l}\text { Animación } \\
\text { Sociocultural }\end{array}$ & Escolar-psicoeducativa & Intervención \\
\hline & & & Biblioterapia \\
\hline
\end{tabular}

\section{LA MEDIACIÓN: DERECHO, INTERVENCIÓN SOCIOCULTURAL Y MEDIACIÓN PEDAGÓGICA}

El concepto de mediación proveniente del Derecho puede entenderse como un procedimiento estructurado en el que dos o más partes en conflicto intentan voluntariamente alcanzar un acuerdo sobre la resolución de sus diferencias con el apoyo de un mediador o mediadores.

La mediación se fundamenta en la confianza y el poder (donde las partes cobran un fortalecimiento) y sus principios son: voluntariedad, confidencialidad, flexibilidad, neutralidad, imparcialidad, equidad, legalidad, economía, buena fe y proactividad. La mediación es un instrumento muy útil, aunque aún existen ciertos obstáculos para que se lleve a cabo, entre ellos se encuentran la resistencia al cambio de los abogados, la resistencia de los jueces y la falta de conocimiento de los justiciables (González Martín, 2010, 621-624).

A la idea de mediación proveniente del Derecho, se le sumó en los años setenta el concepto de mediación cultural, el cual tiene su origen en la pedagogía. Para algunos autores, tiene que ver más con el acceso a la justicia y para otros con el acercamiento a los bienes culturales, lo cierto es que desde una perspectiva más amplia, el disfrute de un bien cultural forma parte del acceso a la justicia. Es decir, al disminuir la distancia entre quienes pueden o no poseer ciertos bienes culturales, también se puede disminuir la brecha entre quienes tienen o no derecho a la justicia.

Según el concepto de la Consejería de Cultura de Valencia, "la mediación cultural contribuye a potenciar los recursos personales y sociales, de que dispone la comunidad educativa, para atender 
aquellas necesidades que puedan generar conflicto o malestar entre sus miembros, por causa de las diferencias culturales". ${ }^{1}$

Por otro lado, el sitio italiano de la imiweb define la mediación cultural como: "una profesión que tiene como objetivo facilitar las relaciones entre los autóctonos de una nación y los ciudadanos extranjeros que emigran a ésta, con la intención de promover el conocimiento recíproco y la comprensión para favorecer una relación positiva entre sujetos de culturas diversas". ${ }^{2}$

En otras definiciones encontramos diversos elementos, como los planteados por María Inés Silva, que afirma que la mediación cultural tiene los siguientes elementos:

1. Acciones que buscan disminuir la distancia física, cognitiva y simbólica entre los objetos culturales y sus públicos.

2. Actividad de producción de sentido en torno a experiencias compartidas por una comunidad sobre objetos culturales y artísticos en un espacio y tiempo definido.

3. Modo particular de intervención y regulación social que porta un imperativo político; constituye la base de una política de democratización cultural que se propone actuar como una pedagogía de la vida social (Silva 2012, 4).

Notamos dos usos distantes del mismo concepto, el primero se refiere a la integración cultural de personas de distintas culturas (el caso de Valencia e Italia) y se encuentra directamente relacionado con la atención a los migrantes. Mientras que el segundo tiene que ver, como lo planteamos al principio, con el acceso a los bienes culturales, dentro de los que se encuentra el libro, la biblioteca y más ampliamente la cultura escrita.

Para Prieto Castillo, la mediación es parte de un proceso amplio que no debe ceñirse a los límites escolares o de un curso en particular; así, el autor afirma que:

1 La mediación cultural en el ámbito educativo, http://www.aulaintercultural. org/IMG/pdf/mediacion2.pdf.

2 www.imiweb.org/spagnolo/mediazione_culturale. 
Cualquier creación del ser humano puede ser utilizada como recurso de mediación [...] es posible mediar con toda la cultura del ser humano, con todos los textos que intentan narrarnos el futuro, con la biografía personal y la vida de otros seres, con las fantasías, con los hechos cotidianos, con la poesía y las fórmulas químicas [...] $(2004,96)$.

Por la misma época, en Europa comenzó a trabajarse la animación sociocultural, la cual tiene elementos comunes con la mediación cultural, entendida desde el acceso a los bienes culturales. Podemos afirmar que la animación sociocultural es el punto de partida para entender la mediación cultural, con la diferencia (muy notable) de que en el caso de la animación hay una práctica política evidente, es decir, no se asume como un espacio neutral, donde el mediador no tiene una postura.

La animación, en general, es cualquier actividad o acción "en o sobre un grupo o colectividad, o un medio que tiende a desarrollar la comunicación y a estructurar la vida social recurriendo a métodos semidirectivos" (Imhof 1971, citado por Besnard 1991, 19), encaminados al desarrollo personal y comunitario.

Besnard afirma que la animación sociocultural surgió como consecuencia de la educación popular, y "se distingue por ser un conjunto de prácticas, actividades y relaciones" (1991, 23-25).

Asimismo, Besnard afirma que la noción de "mediación" le parece restrictiva debido a su superficialidad conceptual. Consideramos que la gran diferencia entre la mediación y la animación sociocultural es que la primera, como explicitamos al principio, está vista como una práctica neutral, mientras la segunda es una práctica política nacida de la educación popular y usada para actuar sobre los vacíos o imposiciones de la educación monopólica ("bancaria", como diría Paulo Freire).

Desde la pedagogía, también se han abordado diferentes formas de mediar: la tradicional y la tecnológica. En la primera se pone énfasis en que el "mediado" (en este caso el alumno) aprehenda el contenido, tal como expone Álvarez del Valle para quien la mediación pedagógica es "el procedimiento por el cual el «mediador", uno de los tres integrantes de la triada: docente-alumno- 
contenido, logra facilitar la resolución del conflicto cognitivo entre las otras partes intervinientes" $(2004,18)$.

La función del mediador es "cuestionar la postura de las partes para lograr la apropiación del conocimiento" (ibid.). En esta definición, tal como en las provenientes del Derecho, para que exista el proceso de mediación debe de haber un conflicto, sólo que en este caso el conflicto es cognitivo y las partes son el alumno y el contenido, mientras que el mediador es el docente.

Legorreta Cortés, por su parte, habla de la mediación en plural (mediaciones) y refiere que éstas son una serie de acciones realizadas a fin de mejorar la interacción entre las partes; éstas comprenden las mencionadas en la definición anterior (contenido, docente, alumno) y agregan los materiales de estudio.

Desde otra perspectiva que enfatiza el hacer posible el acto educativo, Gutiérrez y Prieto definen la mediación pedagógica como el "tratamiento de contenidos y de las formas de expresión de los diferentes temas a fin de hacer posible el acto educativo, dentro del horizonte de una educación concebida como participación, creatividad, expresividad y racionalidad" (Gutiérrez Pérez y Prieto Castillo 1999, 9).

Según Alzate (2005), el término mediación ha sido utilizado ampliamente en la bibliografía posterior a Vigotsky, donde se resalta que en el proceso de aprendizaje son necesarios diversos medios para que se aprehenda la realidad; estos medios pueden ser el lenguaje en todos sus aspectos o cualquier forma de simbolización (imágenes, colores, formas, etc.). Alzate afirma que el postulado, desde esta perspectiva, es "que las mediaciones contribuyen a que las representaciones externas se configuren como representaciones internas, así mismo se conviertan en herramientas para la metaconciencia".

En las concepciones pedagógicas destaca el papel del docente, de la escuela, y de la biblioteca. Olga Valery plantea que el docente debe ser competente como lector y escritor y ser consciente del papel de mediación (2000, 42).

Podríamos trasladar esta visión al bibliotecario; asimismo, la biblioteca no se ve como un espacio para la mediación cultural, ya 
que de ésta se encargan por lo general agentes externos (promotores de lectura, cuentacuentos, guías, docentes).

La mediación pedagógica ha transitado de mediar el contenido de un curso a usar la tecnología para proporcionar dicho contenido. Los elementos principales que incluye este concepto (desarrollado ampliamente por Beatriz Fainholc) (2004) son los contenidos (educativos), la tecnología (como recurso) y la interacción (docente-tecnología-alumno).

Por otro lado, encontramos otra vertiente de la mediación pedagógica enfocada también en la tecnología, cuyo centro es la mediación de los contenidos de los medios masivos de comunicación - específicamente la televisión y el mundo digital—, donde lo que se busca es construir un puente entre el medio y el sujeto (Prieto Castillo 2004). A diferencia de la mediación tecnológica, lo que se busca mediar en este caso es el contenido ya existente de los medios masivos, no así elaborar contenidos programáticos con tecnologías.

Resulta de suma importancia ya que podemos equipararlo a lo que en el ámbito bibliotecológico se trabaja desde la educación de usuarios o formación de usuarios, pues los fines de esta mediación son además de la construcción de puentes antes mencionada, "ofrecer oportunidades de lectura diferentes, recursos para preguntar, espacios para jugar y recrear elementos de la pantalla" (Prieto Castillo 2004, 106).

\section{LA MEDIACIÓN LECTORA}

Ahora bien, se entiende por mediación lectora el "proceso de negociación, transacción espontánea, voluntaria en la que el mediador crea las condiciones motivacionales y afectivas para que el sujeto mediado sienta el interés, la necesidad y el placer de leer, no sólo textos literarios, sino todos los códigos meta y paralingüísticos posibles" (Quizhpe 2012).

La Secretaría de Educación Media Superior de México tiene a su cargo un programa de formación de mediadores de lectura, y si 
bien nunca explicita qué es la mediación lectora como tal, sí tiene una definición de mediador de lectura:

Ser mediador es formar parte de un proceso de aprendizaje, en este caso, el de la lectura. Lo que significa no permanecer fuera, sino involucrarse en lo que el alumno lee, y cómo lo lee, en sus necesidades de conocimiento y las habilidades lectoras que posee, para encontrar los aspectos en los que deberemos ayudar, orientar, y/o complementar al joven lector. ${ }^{3}$

Desde ese enfoque, el mediador también debe conocer los gustos, preferencias de lectura y aficiones del aprendiz. Así como saber cuáles son las limitantes de acceso a la información que este pueda tener para poder recomendar lecturas a las cuales pueda acceder. Así mismo, se afirma que la mediación de lectura no debe ser una actividad exclusiva del profesorado, ya que es necesario involucrar a todos aquellos que conviven con los jóvenes.

En este sentido, es necesario recalcar que la mediación de lectura pone énfasis en los jóvenes y los niños, se le dedica especial atención a aquéllos que están insertos en el sistema escolar.

Para Cerrillo la figura del mediador es muy importante, sobre todo a edades tempranas. Dicha figura generalmente es la de un adulto: los padres, los maestros o los bibliotecarios, ellos son quienes ayudan a los primeros lectores a aproximarse a la lectura, hacen la función de enlace y facilitan el diálogo.

El mediador funciona desde esta visión también como legitimador de la oferta editorial, al tiempo que diferencia lo que está a disposición del público (infantil) y establece una línea entre la lectura escolar y otros tipos de lecturas (Cerrillo et al. 2002, 29 y 30).

Cerrillo y los autores que lo acompañan mencionan también esta confusión de términos que en ocasiones se utilizan indistintamente (promoción, mediación y animación) y aunque no se detienen en los primeros dos, acotan que la promoción está vinculada con las políticas culturales de las colectividades - lo pongo en cursivas

3 Esta definición fue tomada de: http://www.fomentoalalectura.sems.gob.mx/ index.php/maestros/que-significa-ser-mediador. 
porque habrá que pensar si las políticas culturales se dan en las colectividades de manera independiente o si se refieren al papel que juega el Estado en la promoción de la cultura.

Respecto a la animación, no dan una definición como tal, sino que explican cuáles son sus objetivos y sus ámbitos: "el objetivo único de la animación de la lectura debiera ser la mejora de los hábitos lectores de los individuos a quienes se dirige la animación, hasta lograr crear en ellos hábitos lectores estables" (ibid., 83).

Aquí cabe preguntar si lo que se busca es crear un hábito, esto se contradice con lo que afirman otros autores (Freire, Larrosa, Petit, Chartier, entre otros), la diferencia que marcan entre gusto y hábito, entre lectura instrumental y lectura para la vida.

Refiriéndonos a este último concepto "lectura para la vida", en este análisis es necesario incluir lo que hace Paulo Freire (1985) sobre la lectura y su relación con el entorno social y físico, pensando en que la lectura de cualquier texto influye directa o indirectamente en la conformación de ciertos hábitos para la práctica cotidiana.

Dada la trascendencia de Paulo Freire en los procesos educativos, sobre todo en los países subdesarrollados, es importante destacar cómo vivió él su vínculo con la lectura y su mundo, en sus propias palabras: "Al ir escribiendo este texto, iba yo 'tomando distancia' de los diferentes momentos en que el acto de leer se fue dando en mi experiencia existencial. Primero, la 'lectura' del mundo, del pequeño mundo en que me movía; después, la lectura de la palabra que no siempre, a lo largo de mi escolarización, fue la lectura de la 'palabra-mundo'" $(1985,95)$.

\section{LA ANIMACIÓN LECTORA}

La animación lectora, como parte del ciclo de la mediación, se enfoca en las actividades que se puedan desarrollar en torno a la lectura, y con ello incidir o reforzar un hábito lector. María Monserrat Sarto propone como definición de animación aquello que: 
Usa las estrategias en forma de juego creativo y estimula la interioridad, que se apoya en el silencio y la reflexión individual. Estudia $\mathrm{y}$ tiene en cuenta las condiciones del receptor. Necesita la programación, sin la cual toda la labor sería mera dispersión. Y cuenta con el mediador, al que llamamos animador, el verdadero impulsor de la formación lectora $(1998,19)$.

En lo que se refiere a los ámbitos de la animación, Cerrillo los divide en dos tipos: formales y no formales: los primeros son la escuela y la biblioteca; y los segundos, la familia, los clubs de lectura, las tertulias literarias y los medios de comunicación (Cerrillo et al. 2002, p 83). En cuanto a las estrategias y técnicas, se plantea la necesidad de que existan condiciones previas a la animación:

- Que la actividad sea libre, gratuita y continuada.

- Que los libros elegidos sean adecuados a la edad de su destinatario.

- Que los libros elegidos tengan calidad literaria.

- Que sean textos completos.

- Que la experiencia pueda ser comunicada a los demás (ibid., 85).

Al respecto, podemos discutir varias cuestiones; primero nos encontramos con la exigencia de la calidad literaria, ¿qué es esa calidad?, ¿quién la determina?, ¿con qué criterios se establece? No cabe duda de que es necesario procurar que el lector no consuma textos, sino que se aproxime a ellos de forma libre y critica, pero consideramos que filtrar los textos con un argumento de autoridad, resulta peligroso y contradictorio para los fines que la animación persigue.

Si bien existen múltiples enfoques sobre la animación, es importante recalcar que dichas actividades se han centrado en atender a un público infantil, pues como afirma Paredes, "las actividades de animación a la lectura empiezan desde el aprendizaje de los primeros rudimentos lecto-escritores" (Paredes 2005, 256). Desde este enfoque, la lectura como actividad se encuentra ligada a la escritura, pues no es posible aislar una actividad de la otra, ya que animar a leer es también animar a escribir. 
Sin embargo, Rafael Ruela explica por qué usa el vocablo recrear en lugar de animar. Uno de los motivos es porque animar a leer ha perdido el sentido de lo festivo, pues existen innumerables actividades destinadas a ese fin que carecen de placer. Y, por otra parte, considera que después de haber revisado un extenso número de textos que versan sobre el tema, casi todos traen actividades para ser realizadas después del acto de leer, por lo que se pregunta, ¿se pretende animar a leer después de haber leído? (Ruela 1997, 16).

Con el auge de las Tecnologías de la Información y la Comunicación (TIC), dicha labor se ve beneficiada, ya que es posible leer y escribir en ambos soportes (Paredes 2005, 257).

Toledano (2002) propone, entonces, una lista de consideraciones individuales, sociales y escolares que deben tenerse en cuenta al desarrollar proyectos de animación a la lectura con TIC:

- La relación con la lectura es un largo proceso que cada alumno sigue de forma individual. No pueden esperarse éxitos espectaculares a corto plazo.

- La influencia de los primeros maestros y de la propia familia suelen ser dos factores determinantes en la actitud hacia la lectura.

- La tarea de animación a la lectura exige una minuciosa planificación: selección adecuada de textos y actividades antes, durante y después de la lectura.

- Conviene conocer la experiencia lectora de nuestros alumnos. Los modos de trabajar de nuestros compañeros son un buen punto de arranque.

- La lectura no es solo el acercamiento al canon literario. Literatura es lectura.

Al respecto, Garrido afirma que se ha desligado la práctica de la lectura de la práctica de la escritura; en ese sentido, la escritura también debe ser promovida por lo que "los ejercicios de escritura no deberían ser opcionales. Cada quién tiene la libertad de escribir lo que quiera, pero todos tenemos -que el promotor se incluya es muy convincente- la obligación de escribir algo" (Garrido 2012, 37). 


\section{LA PROMOCIÓN DE LA LECTURA}

La animación lectora es diferente de la promoción, ya que esta última pretende generar un cambio tanto individual como social; en ese sentido, la promoción se asemejaría más a la animación sociocultural mencionada anteriormente. Para Didier Álvarez Zapata y Yicel Nayrobis Giraldo, la promoción de la lectura es un:

Esfuerzo dirigido a impulsar un cambio cualitativo y práctico de la lectura y escritura en la sociedad. La promoción de la lectura debe entenderse como un trabajo de intervención sociocultural que busca impulsar la reflexión, revalorización y construcción de nuevos sentidos, idearios y prácticas lectoras, para así generar cambios en las personas, en sus contextos y en sus interacciones $(2010,95)$.

Los autores afirman que la promoción no es un servicio más que presten las bibliotecas, por el contrario, es una acción de intervención que incide en el proceso de cambio de un individuo y de su contexto.

Desde esta perspectiva, no existe un estado ideal de lector, el sujeto no tiene un déficit, uno se encuentra en un nivel inferior respecto al promotor, es, por lo contrario, parte de una estrategia de colaboración (ibid., 96).

Por otro lado, Adela Castronovo señala que "la promoción de la lectura tiene por principal objetivo crear usuarios, practicantes autónomos de la lectura, sea ésta de libros o en otros soportes [y] consiste en aquellas actividades que fomentan la lectura en lugares o momentos en que no es habitual y, fundamentalmente, consiste en todas las acciones tendientes a la formación de lectores" (2007, 9 y 21).

Antoine Rufus Calderón por su parte señala:

Promover la lectura como algo fun, una cosa en "la onda" puede traer muchos más efectos negativos que lo que se pudiera ganar en cuanto a la propia lectura [...]. La promoción verdadera de la lectura, la que garantiza una vocación a largo plazo, pasa por el reconocimiento público y valiente de lo que realmente es, de su función a priori, de distanciamiento enriquecedor entre nosotros y el mundo, y nunca 
debe esconderse bajo pretextos utilitaristas de descanso o diversión que, aparentemente, pueden favorecer su promoción en un muy corto plazo, pero que a la larga tendrían un precio muy alto $(2010,79$ y 83$)$.

Efectivamente, promover la lectura bajo supuestos utilitaristas no puede ser un gusto perdurable en el individuo, sino una necesidad impuesta por la moda, más ligada al consumo que a una forma de vida.

\section{LA LECTURA REPARADORA Y LA BIBLIOTERAPIA COMO OTRAS FORMAS DE MEDIAR}

Hablar de biblioterapia resulta complicado en un ámbito en el cual se acostumbra limitar las funciones y servicios de las bibliotecas a las actividades de conservación, preservación y difusión; no obstante, hemos decidido incluirlo como una especie de mediación lectora ya que, como veremos más adelante, esta práctica engloba algunos enfoques de los conceptos revisados anteriormente: busca promover la lectura, formar lectores autónomos, incidir en su realidad inmediata, propiciar el uso de la imaginación, desarrollar habilidades cognitivas, entre otros.

Si analizamos el sistema de relaciones entre las prácticas, los objetos y los actores, donde la(s) práctica(s) es (son) la(s) lectura(s), entonces el objeto es el libro, el texto (lo legible) y el sujeto es el lector. La experiencia de la lectura va más allá de lo que se puede hacer a nivel institucional o colectivo (pensando en colectividades organizadas) con el fin de acercar la lectura a los sujetos, pues dicha experiencia se instala dentro del individuo que dota de significantes a lo leído.

Así, la biblioterapia puede ser considerada dentro de las mediaciones lectoras si consideramos que la biblioteca debe redefinirse e incluir otros servicios, brindar el espacio físico al público que no es comúnmente lector, pero que necesita de la cultura escrita. Para Grazia Asta, se debe "hacer la biblioteca más funcional en su relación con el público" (1998, 121).

En México, la biblioterapia podría funcionar como parte de las formas de promover la lectura (aquí podríamos discutir un poco el 
concepto de promoción, por ejemplo lo que dice Garrido sobre la desconfianza que le genera el término, ya que cualquier actividad que se presente como gozosa no tendría por qué ser promovida).

Si pensamos en la violencia como problema(s), el ser violentado no es, no se reconoce, no se nombra y no dispone de un lenguaje propio. La lectura hace que se construyan lenguajes propios, que se dote de significado a los procesos y que se pueda construir una narrativa autónoma sobre la experiencia personal. Podemos apoyarnos en Leonor Arfuch:

Si de algún modo las narrativas del yo construyen los efímeros sujetos que somos, esto se hace aún más perceptible en relación con la memoria, en tanto proceso de elaboración de experiencias pasadas, y muy especialmente cuando se trata de traumáticas. Allí, en la dificultad de traer al lenguaje vivencias dolorosas que están quizá semi ocultas en la rutina de los días, en el desafío que supone volver a decir, donde el lenguaje, con su capacidad performativa, hace volver a vivir, se juega [...] la necesidad de decir, la narración como trabajo de duelo $(2010,29)$.

Uno de los problemas a los que nos enfrentamos es cómo hacer uso de la lectura como medio de transformación y como bien cultural si resulta complicado que se acceda a dichos bienes o que se acceda de la misma manera a ellos. ${ }^{4}$ Asta afirma que no todos los sujetos saben hacer uso de los bienes culturales:

Una de las infraestructuras culturales se limita a un estrecho segmento del público que corresponde al público real, mientras que el público potencial y el no público están parcial o completamente excluidos de la provisión del servicio. La consecuencia es una especie de estructura piramidal de tipos de público con diferentes niveles de educación, trabajo, consumo cultural y condiciones sociales $(1998,121)$.

4 Esto tiene que ver con la distribución de las diferentes especies de capital, si bien es cierto que en teoría todos los individuos tienen acceso a los bienes culturales, su consumo varía dependiendo del campo social del que provengan. 
Cabe mencionar que hoy en día es necesario considerar los nuevos recursos de la informática y la comunicación a través de las redes sociales con el propósito de alentar la promoción de la lectura. Esto es así porque muchos textos se presentan en formato digital, lo cual permite que numerosas publicaciones puedan descargarse casi en cualquier sitio del planeta. Si bien estas innovaciones tecnológicas pueden crear más lectores, también han conducido a que las bibliotecas en su formato hayan sido, en cierta medida, rebasadas.

Al respecto, Galato afirma que la estructura de la biblioteca "ha llegado a un punto de crisis y en cierto sentido un punto muerto". Esta crisis en la que ha entrado la biblioteca es una crisis en tres niveles: en la imagen social, en la estructura y en el bibliotecario (Galato 1998, 115).

Por su parte, para Michele Petit "la contribución de la lectura a la reconstrucción de uno mismo tras la desilusión amorosa, un duelo, una enfermedad, etc. — cualquier pérdida que afecte la representación de sí mismo y del sentido de la vida- es una experiencia común y ha sido descrita por numerosos escritores" (Petit 2009, 11).

Esta experiencia común ha sido sistematizada de diversas maneras, ya sea en la experiencia clínica o desde la biblioteca. Por lo que consideramos que podemos hablar de biblioterapia como una forma de mediación lectora. Aunque los objetivos de dichas prácticas sean disímiles, el resultado (aunque no mesurable) podría equipararse.

Tanto en la biblioterapia como en las otras formas de mediar, el proceso no es explícito debido a que es un proceso que se configura en el interior de un individuo. Existe literatura científica en el campo del psicoanálisis, pero aunque una parte de los profesionales que usan la lectura en espacios en crisis usan la palabra biblioterapia, en los contextos en los que Michel Petit ha trabajado no es usada, ya que "como su nombre lo indica lo que se espera ante todo es un resultado terapéutico; sin embargo, la mayoría de los facilitadores de libros a los que he conocido pretenden actuar en un nivel mucho más amplio que el de la curación, que es de orden cultural, educativo y en ciertos aspectos políticos" (Petit 2009, 22). 
Existe, pues, una importante diferencia entre la práctica clínica y la mediación con enfoque biblioterapéutico: en la primera, el sujeto puede resultar cosificado y con una tendencia individualizante (como en la superación personal). Tiene como ventajas que se puede explorar la relación del individuo con el texto y el proceso (interno) de cambio. Pero también es impositiva, restrictiva y directiva. La segunda, la práctica de la mediación, no ha sido investigada en el proceso pero es evidente que involucra mucho más que un cambio individual, ya que como afirma Petit "cuando una persona o población han sido gravemente afectadas en su existencia misma, su cuerpo, su dignidad, o despojados de sus derechos esenciales, la reparación debería ser por principio jurídica y política" (ibid., 2003). Precisamente por ello el papel de mediador cultural se inserta en diversos espacios, a saber: el jurídico, el político y el terapéutico.

Otra diferencia entre el espacio terapéutico tradicional (biblioterapia) y el de la mediación cultural/lectora es el de la obligatoriedad. En el primero, además, existe una relación jerárquica entre el que sabe (el que proporciona las lecturas) y el que será "curado”. En el segundo (mediación) el proceso será conducido por el "mediado", en ese sentido se asemeja a lo no directivo en la terapia rogeriana, ${ }^{5}$ donde el ambiente que se crea no es de imposición (“itienes que leer esto!”), sino de acompañamiento.

5 Terapia de orientación humanista donde el proceso que se vive es de interacción con el cliente, desde una posición de horizontalidad, que se traduce en los "reflejos" que el terapeuta hace al paciente. Es decir, el terapeuta funciona como "espejo" y el cliente encuentra en ese espejo su propio camino, pues le permite reorganizar su estructura interna. Se sustenta en la aceptación positiva incondicional, el respeto y la empatía, entre otras cosas. Consideramos que la mediación, específicamente desde la idea de la lectura reparadora, tiene semejanzas con la terapia rogeriana, dado que el texto sirve como espejo para que el lector "se vea" al tiempo que le permite reestructurar o reacomodar sus experiencias vitales. Podemos traducir esto dentro de la experiencia lectora en las frases "me identifiqué mucho con el personaje", "es como si lo hubiera escrito yo", "comprendí cosas que me han pasado”, entre otras. La experiencia aquí va más allá del gusto estético o del hábito de lectura. Se convierte, en suma, parafraseando a Michelle Petit, en una experiencia vital. 
El objetivo es que a través de esta práctica se puedan formar lectores autónomos. Tal es la idea de Garrido: "Un lector autónomo es alguien que, además de realizar todas las lecturas utilitarias que necesite y deba hacer, dedica un tiempo, día por día, a leer por su propia voluntad, por el interés en la lectura misma y el gusto de leer" (Garrido 2012, 20).

\section{SOBRE LA MEDIACIÓN Y LA AUTONOMÍA DEL LECTOR}

Siguiendo la idea de Adela Castronovo, el objetivo de la formación de lectores es el de construirlos como autónomos y críticos, y que con el acceso a la información sean capaces de procesarla y transformarla en conocimiento.

Al respecto, Devetach habla de la "construcción del camino lector", y hace énfasis en el papel que han jugado históricamente las mujeres como narradoras, como transmisoras de cuentos, tradiciones, leyendas e incluso normas morales, con lo que puede advertirse una clara escisión entre la lectura pública y la lectura privada, división que persiste hasta nuestros días. A éstas se les otorgan los nombres de "lectura profesional" (pública) y a lectura privada nosotros le llamaremos "autónoma" debido a las características que describiremos en seguida.

El primer tipo de lectura se da desde los "puestos de educadoras, de textos útiles, que cuentan con el consenso general" (Devetach 2008, 27). El segundo tipo de lectura requiere de privacidad, pues "pone en juego nuestras disponibilidades más profundas, que permite el ensayo y el error, el detectar el momento de la necesidad de recurrir a los otros [...] y de autonomía para irse independizando" (ibid.).

Por otro lado, Adela Castronovo hace algunas consideraciones acerca de la fotocopia de libros. Sin embargo, notamos contradicciones, pues, por un lado, habla de la autonomía del lector, y, por el otro, impone la lectura desde el soporte tradicional (libro): 
De alguna manera, quienes estamos en el mundo del libro debemos redoblar la lucha contra la instauración y naturalización de la lectura por sus dos aspectos negativos: el legal y el referido a su utilidad como elemento de lectura. El placer de leer con un libro entre las manos, de disfrutar del color, del olor y la textura del papel y adueñarse del libro como objeto no puede ser reemplazado por una fotocopia y es necesario buscar alternativas para que el libro no vaya perdiendo su lugar en el ámbito de estudio. Porque el libro fotocopiado es en definitiva, un atentado contra la formación de lectores, es necesario que libreros y bibliotecarios tomen conciencia de esto para que puedan transmitir este convencimiento a los docentes en todos los niveles de enseñanza [...] (Castronovo 2007, 31).

En este sentido, tenemos dos conceptos antitéticos: autonomía versus terapia:

Todos aquellos que creen que saben lo que es la salud, que hacen de ese saber una forma de poder, y que se han arrogado el dudoso derecho de tutelar la salud espiritual, mental o moral de los demás, han tenido el buen cuidado de exterminar o al menos de vigilar atentamente los libros potencialmente peligrosos y de imponer o al menos promocionar los libros saludables (Larrosa 2003, 192).

¿Se puede empatizar con el texto? ¿El texto puede empatizar con el individuo? Dice Petit que "a lo largo de nuestra vida, buscamos pelotas que nos mandan los demás a nuestra cancha, las cuales nos permiten discernir mejor lo que hay alrededor de nosotros y sobre todo lo que nos sucede a nosotros de manera inexpresable. Necesitamos al otro para 'revelar nuestras propias fotografías"' (Petit 2009, 47).

Esto nos remite a la relación con el terapeuta (Rogers, enfoque centrado en la persona) donde se utilizan una serie de herramientas (reflejos) que tienen por finalidad regresarle al individuo su propio sentimiento.

Petit explora la relación existente entre la primera oralidad (que se da en la infancia con los cuentos, las rimas o las canciones) y el gusto por la lectura y la apropiación de la cultura escrita: "Leer es 
también volverse autónomo: el libro está hecho de signos, de lenguaje, de ese registro simbólico que los psicoanalistas sitúan más bien del lado del padre, de una instancia tercera que separa al hijo de su madre" (ibid., 63).

Por otro lado, podemos señalar que existe una autonomía relativa del lector manifestada en forma de "censura" que abarca tanto la lectura pública o profesional, como la lectura privada o autónoma y que obedece a cuestiones de carácter social, político y económico, vinculados entre sí.

Dicha obediencia debida también se hace notar al momento en que cualquier agente mediador de lectura — de los que hemos hablado antes - impone, juzga o filtra algún texto usando su poder simbólico, y le resta así autonomía al individuo.

La autonomía también puede ser filtrada por el espacio social en que se dé la práctica lectora, por lo que, como agentes mediadores de lectura, debemos también preocuparnos por mantener el espacio de la mediación, no neutral, sino libre y autónomo.

\section{CONCLUSIONES}

Si bien no hay un consenso entre los conceptos relacionados a las diferentes prácticas de mediación lectora, podemos destacar que todas persiguen de alguna manera la misma idea: generar tanto ambientes de lectura como sujetos lectores. También notamos que la biblioteca se encuentra en la mayoría de los casos opacada como agente de cambio dentro de las prácticas de mediación, pues los agentes que se mencionan mayoritariamente son los maestros, padres de familia y profesionales en su calidad de mediadores o animadores a la lectura. La institución bibliotecaria debe no solo renovarse, sino adecuarse a las nuevas formas de leer, para que cualquier esfuerzo de mediación (traducido en actividades de animación, promoción, invitación, etc. que surjan del entorno bibliotecario) tenga eco en los usuarios y genere resultados relevantes. 


\section{BIBLIOGRAFÍA}

Alvarado, E. 2007. La importancia del lenguaje en el fomento a la lectura. México: Conaculta.

Álvarez Zapata, D. e Y. Nayrobis Giraldo. 2010. “¿Fomento, promoción o animación a la lectura?: Un acercamiento conceptual a lo que la biblioteca pública hace con la lectura". En Tercer seminario Lectura: pasado, presente y futuro. Compilado por Elsa M. Ramírez Leyva. México: CUIB-UNAM.

Alzate Piedrahita, M. V., M. C. Arbeláez Gómez et al. 2005. Intervención, mediación pedagógica y los usos del texto escolar. Revista Iberoamericana de eEducación 37, 3.

Arfuch, L. 2010. Sujetos y narrativas. Acta Sociológica, 53: 19-41.

Asta, G. 1998. "Enseñar al público a ser activo". En $E l$ público y la biblioteca: metodologías para la difusión de la lectura. España: Trea.

Bersnard, P. 1991. La comunicación sociocultural. Barcelona: Paidós.

Brown, F. E. 1975. Bibliotherapy and Widening Applications. Metuchen: The Scarecrow Press.

Castronovo, A. 2007. Nuevas propuestas en promoción de la lectura. Buenos Aires: Colihue.

Cerrillo, P. C.; E. Larrañaga y Yubero, S. 2002. Libros, lectores y mediadores. La formación de los hábitos lectores como proceso de aprendizaje. Cuenca: Ediciones de la Universidad de Castilla-La Mancha.

Devetach, L. 2008. La construcción del camino lector. Córdoba: Comunic-arte.

Fainholc, B. 2004. El concepto de mediación en la tecnología educativa apropiada y crítica. Educ.ar. Disponible el 25 de junio de 2017 en http://bit.ly/2vGygFF. 
Freire, P. 1985. La importancia de leer y el proceso de liberación. México: Siglo XXI.

Galato, F. 1998. "Crear voluntad colectiva de cambio. Notas para la definición de la biblioteca democrática". En El público y la biblioteca: metodologías para la difusión de la lectura. España: Trea.

Garrido, F. 2012. Manual del buen promotor. Una guía para promover la lectura y escritura. México: Conaculta.

Gutiérrez Pérez, F. y D. Prieto Castillo. 2007. La mediación pedagógica: Apuntes para una educación a distancia. Buenos Aires: La Crujía.

Larrosa, J. 2003. La experiencia de la lectura: estudios sobre literatura y formación. México: Fondo de Cultura Económica.

Martínez de Sousa, J. 2004. Diccionario de bibliología y ciencias afines. 3ra. ed. España: Trea.

Paredes Labra, J. 2005. Animación a la lectura y TIC : creando situaciones y espacios. Revista de Educación. Número extraordinario.

Petit, M. 2009. El arte de la lectura en tiempos de crisis. México: Océano Travesía.

Prieto Castillo, D. 2004. La comunicación en la educación. Buenos Aires: La Crujía.

Quizhpe, A. 2012 "Estrategias básicas de mediación lectora”. Segunda entrega. Diario Centinela. Disponible en: http://diariocentinela.com.ec/estrategias-de-mediacion.

Ruela, R. 1997. Recrear la lectura. Actividades para perder el miedo a la lectura. Madrid: Narcea.

Rufus Calderón, A. 2010. "El sentido de la lectura". Segundo premio "Mauricio Achar. El señor de los libros" del ensayo sobre Fomento a la Lectura. México: Educal. 
Sarto, M. M. 1998. Prólogo. En M. M. Sarto y J. A. Marina. Animación a la lectura: con nuevas estrategias. Madrid: Ediciones SM.

Silva, M. I. 2012. ¿De qué hablamos cuando hablamos de mediación cultural? Ponencia presentada en el II Seminario Internacional "Desafíos de las Políticas Culturales en Chile: Experiencias de desarrollo cultural". Santiago: Observatorio de Políticas Culturales.

Valery, O. 2000. Reflexiones sobre la escritura a partir de Vygotsky. Educere 3, 9. 


\title{
Mediación, procesos del pensamiento y lectura analítico-crítica en el currículo de Bibliotecología. Trilogía fundamental para la formación de lectores
}

\author{
Johann Pirela Morillo \\ Universidad de La Salle, Colombia
}

\section{INTRODUCCIÓN}

\begin{abstract}
O aborda la mediación del conocimiento como el proceso a partir del cual los bibliotecólogos pueden asumir acciones para la formación de lectores, con base en la incorporación del desarrollo de procesos de pensamiento y de lectura analítico-crítica en el currículo de Bibliotecología. Algunos referentes teóricos que permiten fundamentar estas ideas son los expuestos por Inciarte, Parra y Bozo (2010), Inciarte y Cánquiz (2010), Kabalen y de Sánchez (2011) y las reflexiones que se han construido como resultado de la experiencia docente en asignaturas relacionadas con el desarrollo de procesos de pensamiento, lectura crítica y producción de conocimiento en Escuelas y Programas de Bibliotecología de las Universidades del Zulia en Venezuela y de La Salle en Colombia.

Los planteamientos que mostramos permiten ampliar la comprensión de la lectura analítico-crítica no sólo en su dimensión instrumental, que la ubica como una competencia transversal y general para todas las profesiones, sino que, en el caso de la formación bibliotecológica, saber leer - y de forma analítico-crítica-
\end{abstract}


implica desarrollar todo un sistema de pensamiento que lleva a ver la lectura en una dimensión de herramienta medular para que los bibliotecólogos den el salto cualitativo y participen en procesos de formación como de lectores críticos y significativos, sin lo cual no será posible transitar hacia la noción y realidad de las sociedades de la información y del conocimiento, basadas es la agregación de valor a la información y la producción de conocimiento útil.

En el ámbito de estas ideas, proponemos que para avanzar hacia una educación bibliotecológica que empodere a los bibliotecólogos como formadores de lectores analítico-críticos, primero es necesario introducir en los planes de estudio de Bibliotecología los contenidos, las experiencias de aprendizaje y las estrategias que garantizarán la superación del problema, relacionado con el débil manejo de la competencia lectora y permitiendo que los profesionales de Bibliotecología se formen como lectores críticos. Lo primero que habrá que hacer es que los futuros bibliotecólogos se formen como lectores con estas características, lo que conduce además a fortalecer no solo el currículo de las escuelas de Bibliotecología, sino también los procesos y las competencias para la mediación del conocimiento, sustentándolas en el desarrollo de procesos de pensamiento y la lectura analítico-crítica.

\section{LA FORMACIÓN DEL BIBLIOTECÓLOGO COMO MEDIADOR DE LECTURA EN EL MARCO DE LA INTEGRALIDAD CURRICULAR}

Si partimos de la idea de que la mediación del conocimiento implica un conjunto de procesos mediante los cuales se generan acciones sistemáticas de intervención entre el espacio de producción de mensajes, contenidos intelectivos y su recepción crítica y significativa por parte de usuarios en estados de total reciprocidad, se asume la mediación como un elemento que permite orientar los procesos formativos en el marco del enfoque por competencias profesionales, que no solamente plantea la adquisición de habilidades y destrezas técnicas, sino que también se incluyen la ética, 
la estética, la visión ecológica y la responsabilidad social de la acción profesional.

Los procesos de mediación del conocimiento, como constructo conceptual integrador, se fundamentan en una perspectiva interdisciplinaria que, une por una parte, los procesos de mediación y, por la otro, el conocimiento en sí. En este sentido, se recurre a enfoques globales propios de las ciencias de la información, de la comunicación y las denominadas ciencias cognitivas, cada una de las cuales aportarán elementos para interpretar y comprender la naturaleza y el alcance de dichos procesos en las bibliotecas y otros servicios de información, entendidos a partir de la idea de organizaciones del conocimiento.

En el currículo por competencias, utilizado en la Escuela de Bibliotecología y Archivología de la Universidad del Zulia, se estimaron los procesos de mediación del conocimiento como elementos orientadores de la formación. Así, se estructuró un perfil integrado por trece competencias: ocho generales dos básicas y tres específicas. Dentro de las generales, se encuentran las que apoyan la mediación, como la identidad cultural, el pensamiento crítico, la comunicación, las tecnologías de información y la investigación.

Dentro de las básicas, además del componente mediador, también se incluyó el conjunto de saberes y prácticas básicos que pueden compartir los bibliotecólogos con otros profesionales que también son mediadores, tal es el caso de los docentes y los comunicadores sociales, entre otros.

En cuanto a las específicas, tenemos las de organización del conocimiento, gestión de recursos y servicios, y conservación y difusión del patrimonio cultural, las cuales se apoyan teórica y conceptualmente en el proceso de mediación del conocimiento.

Este perfil expresa una tendencia muy marcada hacia la mediación del conocimiento, para lo cual el desarrollo de competencias de lectura y de pensamiento crítico es fundamental y debe hacerse parte de la transversalidad curricular en la formación de los futuros bibliotecólogos.

Ahora bien, frente a estos planteamientos, y siguiendo a Inciarte y Cánquiz (2010), la integralidad se enfoca hacia todas las dimensiones 
y complejidades del ser humano, con sus necesidades biológicas, afectivas, sociales y profesionales, de allí que se debe atender la formación humanística y la formación científico-tecnológica.

En palabras de estas dos educadoras venezolanas, la integralidad se manifiesta en un modelo curricular que apuesta a la unión de los saberes fundamentales: el conocer, el hacer, el ser, el sentir, el convivir, entre otros. Además, creemos que la integralidad también debe darse en la formación de lo biológico, psicológico, estético y espiritual, aspectos que a nuestro juicio han estado desatendidos. Para esto el currículo debe ser flexible, abierto a las oportunidades del entorno, en corresponsabilidad con este, y aún más, integrado y sustentable.

Por su parte, Inciarte, Parra y Bozo (2011), señalaron que la Universidad - la del Zule, por supuesto- debía continuar siendo la encrucijada de todos los modos de pensar, especialmente el crítico, para lo cual se requería del desarrollo de competencias generales y específicas, en las que tenían que combinarse conocimientos, habilidades y destrezas técnicas con saberes y prácticas que permitieran el fortalecimiento de los enfoques humanísticos, sociales, científicos y tecnológicos.

Es en el contexto de la integralidad curricular y del componente mediador de la formación bibliotecológica donde queremos fundamentar los criterios que deben guiar la formación de bibliotecólogos como formadores de lectores. Sin embargo, es necesario desarrollar acciones para superar el problema del cual habla Alfaro (2009), es decir, que no es posible formar como lectores a los usuarios si quien quiere cumplir esta función no lo es; en otras palabras, los bibliotecarios no son lectores. Rodríguez Gallardo (2008) también se había referido al problema del débil manejo de la competencia lectora por parte de los bibliotecarios.

Por ello, para enfrentar este problema es importante introducir experiencias formativas en las escuelas de Bibliotecología que conduzcan hacia la apropiación, no solo del gusto por la lectura, sino también - y mucho más importante- del despliegue de acciones concretas de una lectura analítico-crítica, como sustrato esencial que potencie la formación de los futuros bibliotecólogos 
como lectores, con lo cual, estamos seguros de ello, sí existirían condiciones para que estos sean formadores de lectores.

\section{LOS PROCESOS DE PENSAMIENTO Y LA LECTURA ANALÍTICO-CRÍTICA}

El tema de los procesos de pensamiento en la enseñanza en general, y en la lectura de textos en particular, permite reconocer el enorme potencial que encierra el dominio de estos procesos. Según la visión de Machado (1998), apropiarse de estos implica aprender a utilizar con efectividad las operaciones intelectivas, las cuales son asumidas por ese autor como etapas que pueden ser aprendidas. Tales etapas son: seleccionar, ordenar, analizar, sintetizar, vincular, diferenciar, semejar, trasladar, juntar, apartar, transformar, temporalizar, personificar y expresar.

El autor define cada etapa o proceso como sigue: seleccionar consiste en escoger un ente u objeto entre todos los que se conocen; ordenar significa decidir y disponer las etapas, los pasos o los medios conducentes a la creación de una obra; analizar consiste en descomponer una cosa en sus partes y considerarlas una a una, como quien desmonta las piezas de un todo; sintetizar, por el contrario, implica componer un todo, como quien forma un conjunto uniendo elementos diversos, según una visión personal; vincular es un proceso que implica establecer conexiones entre elementos o fenómenos; diferenciar consiste en considerar las desigualdades que existen entre los objetos y fenómenos; semejar es sopesar las afinidades que pueden plantearse en torno a un conjunto de objetos dados; trasladar supone aplicar elementos propios de un objeto o situación a otro objeto o situación distinta; juntar es unir un objeto o propiedad a otro objeto; apartar es desunir una propiedad de uno o varios objetos; transformar implica convertir un objeto o concepto; temporalizar es atribuir, llenar una cosa de tiempo, darle contextualización histórica; personificar es encarnar una cosa u objeto en la vida y atribuirle acciones del ser personal; por último, expresar supone manifestar un pensamiento por medio de uno o varios signos exteriores. 
La propuesta de caracterización y definición de los procesos de pensamiento de Amestoy de Sánchez (1998) es similar a la de Machado (1998) en lo referente a alcanzar el dominio de las habilidades para conducir con efectividad el pensamiento hacia el logro de objetivos académicos y personales. La visión de Amestoy se sintetiza con el conocido "Paradigma de los Procesos de Pensamiento", hecho dentro del currículum de bachillerato del Instituto Tecnológico de Monterrey y basado en el "Proyecto Inteligencia" elaborado por la Universidad de Harvard y el Ministerio de Educación de Venezuela durante la década de los ochenta, que se formaliza a través de un programa que se interesa en desarrollar las habilidades intelectuales de los estudiantes.

Este paradigma se fundamenta en los siguientes postulados:

1. La inteligencia, si bien es cierto que tiene un fuerte componente hereditario, puede ser desarrollada.

2. Las personas poseen procesos cognitivos que, con una estimulación adecuada, generan estructuras de procesamiento cada vez más complejas que se constituyen en habilidades para pensar.

3. Las habilidades se adquieren y desarrollan con la práctica.

4. La práctica de las habilidades cognitivas a desarrollar requieren de acciones conscientes y deliberadas.

5. La concientización de los procedimientos a seguir en la práctica de una habilidad genera otras metacognitivas, tales como la planeación, la supervisión y la evaluación.

Según este paradigma, los procesos básicos son nueve: observación, comparación, relación, clasificación simple, ordenamiento, clasificación jerárquica, análisis, síntesis y evaluación. Ahora bien, estos mismos procesos pueden también entenderse como el sustrato de las habilidades y estrategias para la lectura analítico-crítica, definida por Kabalen y Amestoy de Sánchez (2011) como aquella que requiere para su ejecución el dominio de tres niveles de apropiación de estrategias cognitivas como observación, comparación, 
relación, clasificación (simple y jerárquica), conceptualización; cambios, secuencias y transformaciones; análisis, síntesis, evaluación y las analogías verbales. Así, leer analítica y críticamente implica que los sujetos dominen en primer lugar todos estos procesos y en función de dicho dominio se desplieguen acciones de lectura literal, inferencial-interpretativa y analógico-crítica.

Las metodologías centradas en la enseñanza de los procesos básicos del pensamiento incluyen el desarrollo de ejercicios para automatizar la práctica de pensar de manera sistemática, organizada y deliberada. En palabras de las autoras del "Modelo de lectura analítico-crítica”, Kabalen y Amestoy de Sánchez (2011), cuando estos procesos se aplican en la lectura de diversas fuentes de información, se convierten en estrategias que permitirán transferir las prácticas del "aprender a pensar" en los procesos de decodificación y apropiación del saber.

Las implicaciones que este "Modelo de lectura analítico-crítica" tiene en la formación bibliotecológica es de fundamental importancia porque no solo aportará a los estudiantes los elementos necesarios para enfrentarse a todo tipo de textos, con la garantía de su comprensión profunda, sino que también su aplicación hará mucho más significativa la formación instrumental de los bibliotecólogos, quienes no solamente deberán utilizar la lectura analítico-crítica como base de la organización del conocimiento, sino también como punto de partida para la formación de lectores en todo tipo de bibliotecas: escolares (enseñanza básica, media superior y superior), públicas y privadas, especializadas (investigación, científicas) y nacionales.

De modo que si se asume el carácter mediador de la formación de los futuros bibliotecólogos, y a su vez si se tiene en cuenta el desarrollo de procesos de pensamiento como sustrato del desarrollo de la lectura analítico-crítica, se asegurarán mayores posibilidades para que los profesionales de la información participen activamente en tareas que conduzcan hacia la formación de lectores críticos y significativos. 


\section{LA LECTURA ANALÍTICO-CRÍTICA EN EL CURRÍCULO} DE Bibliotecología. CASOS: Universidad del Zulia, VENEZUELA Y UNIVERSIDAD DE LA SALLE, COLOMBIA.

La lectura analítico-crítica es un proceso que permite adentrarse en la estructura de los textos y desarrollar operaciones cognitivas que van mucho más allá de ver la lectura como la simple decodificación de los símbolos y significados presentes en todo tipo de textos y discursos. De esta forma, la lectura analítico-crítica se ubica en un modelo de comprensión y de interpretación que reconoce la existencia de tres niveles fundamentales que deben dominarse para alcanzar una formación como un lector analítico y crítico. Estos niveles discurren desde lo literal, pasando por lo inferencial-crítico, hasta llegar a lo analógico, este último nivel implica además el dominio de procedimientos intelectivos basados en la relación y extrapolación de lo que sucede de un ámbito a otro.

Los tres niveles de lectura implican que se utilicen los procesos básicos del pensamiento como estrategias cognitivas que garantizan la descomposición, recreación e integración permanente de los contenidos presentes en los textos y discursos de todo tipo.

El nivel literal consiste en entrar en contacto con los contenidos a los cuales hace referencia la información expresada en los textos. En este nivel se aplican los ocho procesos básicos del pensamiento, y se entienden como secuencias de procedimientos que tienen que ver con la sistematización de la observación, comparación, clasificación (simple y jerárquica), conceptualización, cambios, secuencias y transformaciones; análisis, síntesis y evaluación. El segundo nivel de lectura, denominado inferencial-crítico, se apoya en los procesos del nivel literal, pero introduce elementos de la decodificación textual y la inferencia, como los razonamientos inductivos y deductivos, la argumentación, la identificación de falacias en el pensar, la lectura y el proceso de discernimiento. Finalmente, el tercer nivel de lectura, denominado lectura analógica, tiene por base el pensamiento relacional y la construcción de las analogías verbales. 
Cabe mencionar que el "Modelo de lectura analítico-crítica" no solo permite a los futuros bibliotecólogos asumir que el dominio de la lectura tiene un carácter instrumental, cuya finalidad alcanza a todas las esferas de la vida, por ejemplo la académica y la personal, sino que también ofrece herramientas muy importantes para realizar procesos de escritura siguiendo los patrones y criterios señalados en cada nivel de lectura.

De esta forma, el "Modelo de lectura analítico crítica" es muy importante para dotar a los futuros bibliotecólogos de las herramientas que les permitan empoderarlos como formadores de lectores, sobre todo en un tipo de lectura particular, aquella que es el resultado de la aplicación sistemática de los procesos de pensamiento al análisis crítico de la información textual, es decir, aquella que se encuentra disponible en todo tipo de textos.

En el caso de la Escuela de Bibliotecología y Archivología de la Universidad del Zulia, desde el año 1999 se incluyó en el plan de estudios una asignatura relacionada con el desarrollo de competencias para la lectura analítico-crítica, que se estructuró con base en los postulados del "Paradigma de los procesos de pensamiento" señalados por Amestoy de Sánchez (1998). Es de reconocer que desde que se emprendió esta acción, no solo se ha logrado preparar a los futuros profesionales de nuestra rama para que se apropien de las estrategias indicadas en el "Modelo de lectura analítico-crítica", con sus implicaciones en lo instrumental, sino que además se establecen relaciones entre las habilidades de lectura analítico-crítica y otras asignaturas de la formación profesional específica, como es el caso de las materias referidas al análisis de la información.

Este empalme logrado entre la asignatura denominada homónimamente "Lectura analítico-crítica" y el eje de formación profesional específica, vinculado con la organización del conocimiento, ha permitido que los estudiantes vean los procesos de análisis formal y de contenido, como parte del análisis crítico de los textos; es decir, para poder evidenciar dominio en cuanto a los procesos de catalogación, indización y resumen, se requiere dominar primero los procesos de pensamiento aplicados a la lectura analítico-crítica y sus niveles de abordaje: literal, inferencial y analógico. 
La experiencia en el dictado de esta asignatura ha permitido que los bibliotecólogos en formación valoren la lectura no solo en su dimensión transversal, sino en su carácter esencial, para impulsar procesos de formación de lectores en todo tipo de bibliotecas y otros servicios de información. Cabe mencionar que las técnicas didácticas que se han privilegiado en la asignatura mencionada no solo han estado relacionadas con textos escritos, sino también se han incorporado la lectura de textos sonoros y fílmicos, con lo cual se ha pretendido ampliar la concepción de documento y de texto, considerando la escritura impresa y otros tipos de escrituras y de discursos, en donde se expresan mensajes intelectivos igualmente significativos, como es el caso de los textos escritos.

En el caso del "Programa de Sistemas de Información y Documentación, Bibliotecología y Archivística” de la Universidad de La Salle, en Colombia, se han incorporado contenidos y estrategias propios del "Modelo de lectura analítico-crítica" en la asignatura denominada "Producción del conocimiento en el sistema de información”, que, ubicada en el primer semestre del programa referido, busca iniciar a los estudiantes en la adquisición sistemática y desarrollo de competencias para abordar el proceso de investigación, comenzando por el dominio, en primer lugar, de las estrategias cognitivas aplicadas a la lectura analítico-crítica de los textos, y en segundo lugar la transferencia de los procesos cognitivos como base de la evaluación de todo tipo de textos y discursos.

En esta materia, se ha introducido el "Modelo de lectura analítico-crítica", como el conjunto de procesos y operaciones cognitivas que permiten apropiarse de la lectura valorando los tres niveles mencionados: literal, inferencial y analógico-crítico; por otra parte, el modelo aporta elementos para evaluar textos, en términos de evidenciar fortalezas, vacíos o posibles omisiones que pueden cometer los escritores, cuando elaboran sus escritos. Esta evaluación se hace con base en los patrones de organización textual y en la detección de posibles falacias en los procesos de argumentación que reproducen formas específicas a partir de las cuales se estructura el discurso, atendiendo a las diversas posibilidades para presentar la información y las ideas que apoyan los textos. 


\section{CONCLUSIONES}

En el currículo de las Escuelas de Bibliotecología se deben considerar los procesos de mediación del conocimiento como componentes orientadores de la formación. En este sentido, se debe garantizar que los perfiles de los bibliotecólogos incluyan la posibilidad de que sean formadores de lectores, sobre todo en ámbitos de bibliotecas escolares y públicas, tipologías bibliotecarias que tienen el compromiso de apoyar los procesos educativos y de incremento del acervo cognitivo y cultural de los estudiantes de todos los niveles educacionales, basados en la idea de educación a lo largo de la vida, cuya piedra angular es el desarrollo de competencias para la lectura analítico-crítica.

Para lograr este objetivo, se requiere incorporar el estudio de propuestas de desarrollo del pensamiento y de la lectura, como es el caso del "Modelo de lectura analítico-crítica", el cual tiene una alta potencialidad en la formación bibliotecológica, porque no solo aportará a los estudiantes los elementos necesarios para enfrentarse a todo tipo de textos, sino que además dicho modelo es un referente esencial para la formación lectora basada en el dominio de operaciones intelectivas, como por ejemplo observación, comparación, relación, definición de conceptos, características esenciales, planteamiento y verificación de hipótesis, análisis, síntesis, evaluación, analogías verbales e interpretación.

En la Escuela de Bibliotecología y Archivología de la Universidad del Zulia de Venezuela y en el "Programa de Sistemas de Información" de la Universidad de La Salle en Colombia, se han instrumentado acciones orientadas hacia la incorporación del "Modelo de lectura analítico-crítica”, como una apuesta para que los bibliotecólogos se formen como lectores críticos y significativos, y que sobre esta base se conviertan en formadores de lectores bajo los principios del análisis crítico de textos, con ello se espera superar el problema planteado al inicio de este escrito, en relación con la necesidad de que los bibliotecólogos se apropien de las herramientas y metodologías que permitan realizar procesos de lectura crítica de la información disponible en una variedad de formatos y soportes, como los impresos, visuales, sonoros y digitales. 


\section{BIBLIOGRAFÍA}

Alfaro L, H. G. 2009. Los bibliotecarios y la formación de lectores. Investigación Bibliotecológica 23, 49 (septiembre-diciembre). México: UNAM. Disponible en: http:// www.scielo.org.mx/scielo.php?script=sci_arttext\&pid= S0187-358X2009000300007 Fecha de consulta: mayo 16, 2013.

Amestoy de Sánchez, M. 1998. Desarrollo de habilidades del pensamiento. Manual del curso. Caracas: Centro de Investigación para el Desarrollo del Pensamiento.

Inciarte, A., M. Parra y A. Bozo. 2011. Reconceptualización de la Universidad. Una mirada desde América Latina. Maracaibo: Ediciones Astrodata.

Inciarte, A. y L. Cánquiz. 2010. Formación integral y currículo por competencias. Disponible el 16 de mayo de 2013 en: http://redaberta.usc.es/aidu/index2.php?option=com docman\&task=doc_view\&gid=484\&Itemid $=8$.

Kabalen, D. y A. de Sánchez. 2011. Lectura, análisis crítico y desarrollo de ensayos. México: Trillas.

Machado, L. A. 1998. La revolución de la inteligencia. El derecho a ser inteligente. Caracas: Cármina.

Rodríguez Gallardo, A. 2008. "Comentario". En La biblioteca pública y la formación de lectores en la sociedad de la información. Memoria. Coordinado por Elsa M. Ramírez Leyva, 182. México: CUIB-UNAM. 
La formación de lectores en el campo de la Bibliotecología. Instituto de Investigaciones Bibliotecológicas y de la Información/UNAM. La edición consta de cien ejemplares. Coordinación editorial, Carlos Ceballos Sosa; revisión especializada, Valeria Guzmán González; cotejo y corrección de pruebas, Valeria Guzmán González y Zyanya Benavides Reyes; formación editorial, Mario Ocampo Chávez. Fue impreso en papel cultural de 90 g. en los talleres AGYS Alevin, S.C., Retorno de Amores, No. 14, colonia Del Valle, C.P. 03100, delegación Benito Juárez, Ciudad de México. Se terminó de imprimir en el mes de junio de 2017. 